Historic, archived document

Do not assume content reflects current scientific knowledge, policies, or practices. 



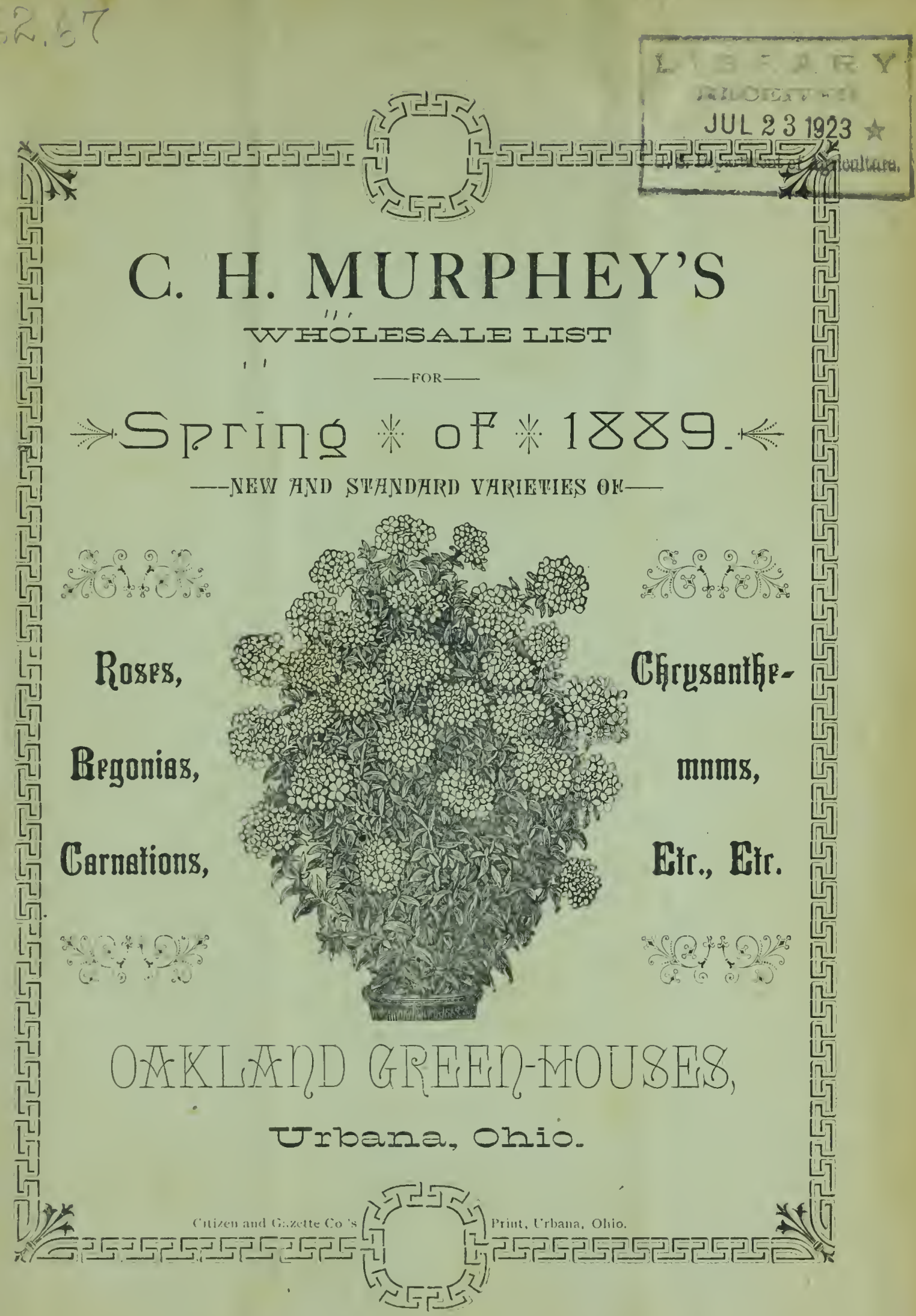





\title{
MO MY PATRORS,
}

To former customers I return my sincere thanks. To new customers who shall favor me with patronage I shall use my best endeavors that one order for my stock shall not be the last, but confident of my ability to please

\section{ASK A TRIAL OF MY PLANTS.}

Notice.-This Price List is for Florists and Dealers only. The prices given are for a general assortment of leading varieties.

\section{HOW SENT.}

All plants will be forwarded by Express unless otherwise ordered. We have the Adams, United States and Wells, Fargo \& Co. Express Companies, by either of which I can secure the lowest possible rates. Parties will please state on which line to forward their goods.

\section{CONDITION OF SALE OF PLANTS.}

The plants named are offered at the rate quoted, six at dozen rates and twenty-five at $\mathrm{IOO}$ rates. No order will be filled from list for a less amount than

\section{TWO DOLLARS.}

Packing is executed with the utmost care. Special pains are taken to pack securely and lightly. All goods are packed FREE OF CHARGE. Everything is carefully labeled, and each plant wrapped separately.

\section{SAFE ARRIVAL GUARANTEED.}

I guarantee the safe arrival of all packages, and also guarantee to give the purchaser satisfaction.

My terms are strictly CASH.

\section{TERMS.}

\section{REMITTANCES}

Should be made by Draft, Postoffice Money Order, Registered Letter or Express Money Order. Remittances in any other way are entirely at the sender's risk.

\author{
C. O. D.
}

Plants to be sent C. O. D. must have one-fourth the amount with the order.

\section{PLANTS BY MAIL.}

At the rates per single plant, I will send by mail postage paid. At per dozen and one hundred, one-fourth addition, but I would earnestly recommend, when it is possible, to have plants sent by express. Address, 


\section{NEW ROSES FOR 1889.}

Madame Hoste-This rose possesses all the requisites of a first-class forcing variety and we predict it will take rank with all of the best forcing varieties of to-day, of strong growth, buds large, fine form and very freely, produced. Color is a light yellow or cream white. 35 Cents each, $\$ 4.00$ per dozen

White Perle-This, Mr. Ritter, the originator, claims is a sport from Perle des Jardines. It is of strong, vigorous growth, producing freely, very fine, white blooms. We do not recommend this for forcing, but it is a remarkable bedding variety for producing buds in sumnıergin the open ground. Each 35 Cents, \$3.00 per 12.

\section{RFINE NATHHLIE DE SERBIE.}

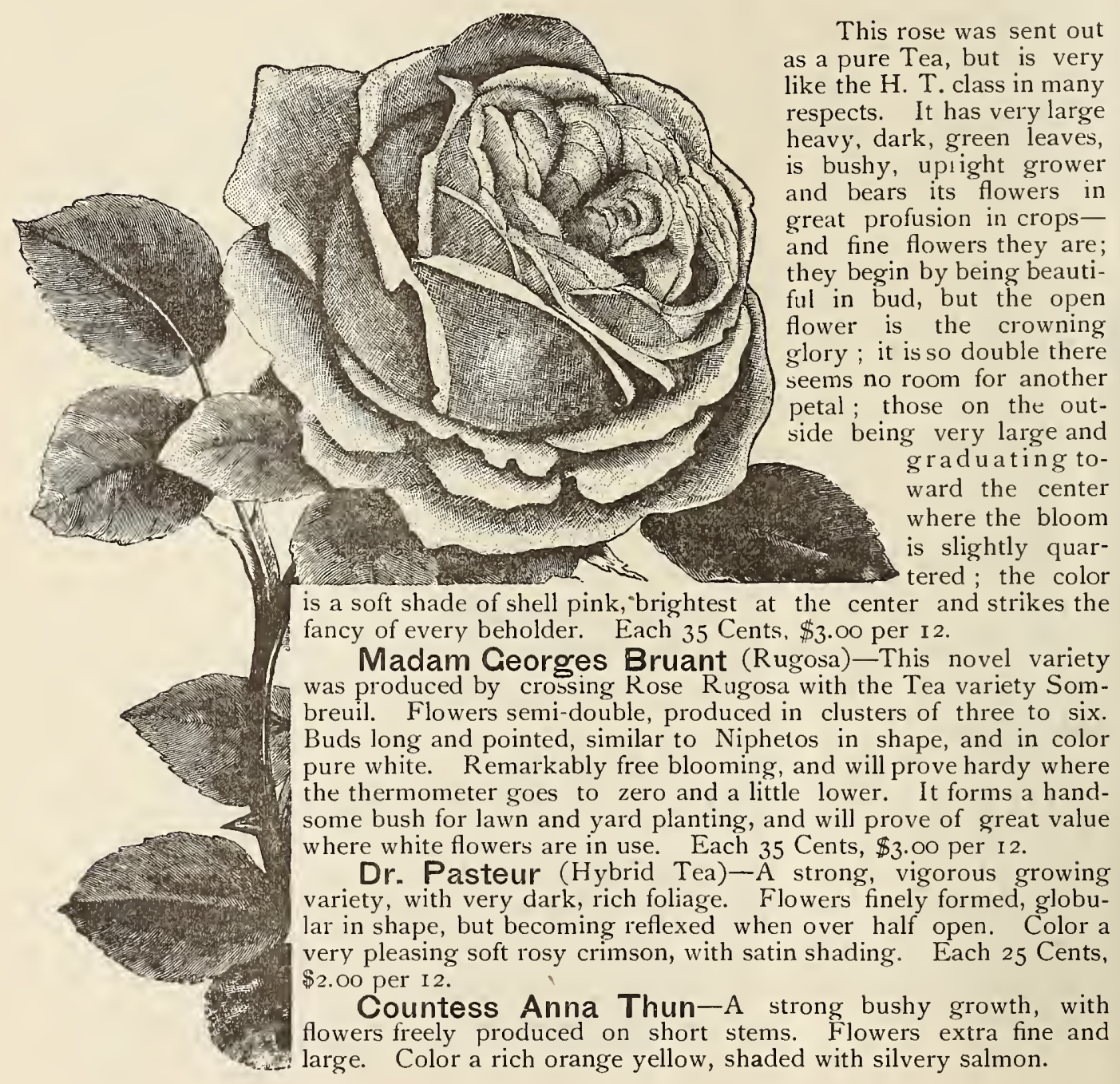


Note. - We recommend this to Catalogue men, for it is a wonderful rose, both in size and color. It is in the line of Comtesse de Nadiallac, but with colors equal to the finest Mad. Margotten ever seen. A good bedding variety. Each 25 Cents, \$2.00 per 12.

Madam Andre Duron-A good, strong growing Hydrid Tea rose, producing extra fine large flowers in great abundance. Color a beautiful bright red, without shadings.

NOTE. - One of the most beautiful roses of the year, and gives" unusual promise of being fine under glass. We had blooms last winter as large as the finest American Beauties. Each 25 Cents, \$2.00 per I 2 .

Madam Ernest Piard (Hybrid Tea).-An enormously strong growing, rampant sort. Flowers semi-double, of a bright red color, shaded with silvery rose.

NotE.-A singular growth; buds long, but sparingly produced. Each 25 Cents, $\$ 2.00$ per I2.

Princess Sagan (Tea).-A very strong, vigorous growing rose, flowering in the greatest profusion, producing medium sized buds and flowers. Color bright crimson velvet, shaded with scarlet ; a most remarkable color among Tea roses.

NotE. - This is the sensational rose of the year, and if the bud proves of sufficient size it will certainly be a real acquisition. It is similar in color to the fine H. P. Louis Van Houtte. Our own prediction is, that it will about equal Bon Silene in size of bud, and also in productiveness. 25 Cents eact, $\$ 2.00$ per 12.

Madam Philemon Cochet (Tea.)-A very thrifty, strong growing Tea Rose, producing cup shaped flowers in the greatest profusion. Color rose, shaded,with salmon, and suffused with a lighter shade.

NOTE. - This will undoubtedly take front rank as a bedding rose, as it combines a strong growth with fine flowers produced in profusion. 25 Cents each, \$2.00 per I 2.

Glorie Des Polyanthas (Polyantha )-A strong, dwarf growing Polyantha, forming a dense, compact growth, literally covered with bloom the entire season. Color "bright rose, shaded with a lighter hue; often comes a deep rosy pink.

Note. - A larger and finer flower than Mignonette, and altogether worthy of culture. 25 Cents each, \$2.00 per I 2 .

Jeanne Ferron (Polyantha.) - A strong, rampant grower, producing fine, large, well formed flowers. Color a dark rosy satin, shaded with flesh.

NotE. - A distinct and beautiful rose. Will make a strong climbing variety in the South. Will be useful. Each 25 Cents, $\$ 2.00$ per I 2 .

The above set of twelve varieties for $\$ 3$ oo.

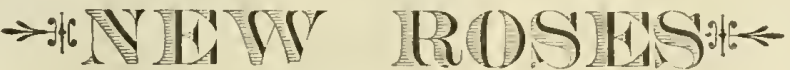

\section{AND VARIETIES WORTHY OF SPECIAL MENTION.}

Princess Beatrice-(Henry Bennett's New Seedling Tea Rose)-A vigorous grower, with stiff, erect wood, thick, handsome foliage, and very free flowering. Flowers well carried on long, stiff stems; large, full, and of the most perfect form; petals round, broad and very thick; outside petals, pale yellow, center, rich golden yellow; edge of petals lightly laced with bright rose. Most distinct and handsome. A pure Tea. Received first-class certificate of the Royal Horticultural Society, London, June 23. I 885. Each I 5 Cents, $\$$ I.50 per I $2, \$ 8.00$ per I00.

Edmund de Biauzat-A strong growing variety. Color, a rose pink, fine flower; grand bedding variety. \$1.00 per dozen; $\$ 8.00$ per 100 .

Meteor-A valuable plant either for pot culture or bedding purpose; of strong, bushy growth, producing large quantities of finely formed, deep crimson scarlet flowers. Very free. $\$ 1.00$ per I $2, \$ 8.00$ per IOO.

Souv. Victor Hugo-Bright china rose, with copper yellow center, ends of petals suffused with carmine. A charmingly beautiful combination of coloring, and each color blends nicely with the other. \$I.00 per I $2, \$ 8.00$ per IoO. 
Souv. Gabrielle Drevet-Salmon pink, with center of coppery rose; of good size and fine form, a beautiful combination of color. Very satisfactory in habit, growth and freedom of bloom. \$I.00 per I2, \$8.00 per I00.

Ye Primrose Dame-A very double variety. Color, outer petals light canary, with rosy salmon center, grand for Florists' use, being as free as a China. Will produce ten flowers to Perle or Niphetoes' one. \$1.50 per I2, \$8.00 per I00.

Chateau des Bergeries-A large canary yellow bud, equal to Perle in size; recommended by its raisers as a winter forcing variety. \$I.00 per I 2 .

Mlle. Perreau-A fine, bold flower; very large. Seedling of Sou. d' un Ami. Pink \$1.oo per I 2 .

Mad. Scipion Cochet-A golden shaded Comptess La Barthe. We think highly of this magnificient rose. \$I.OO per I 2 .

Duchess de Bragance-Light canary yellow. After the style of Coquette de Lyon, but stronger, and of better constitution. \$1.00 per I 2 .

Elizabeth Grammont-Seedling of Perle. Color, bright rose, base of petals coppery-yellow; not a forcing rose, but a magnificent, large, open faced rose. We like it. \$I.0O per I 2.

Madame de Watteville-A strong, vigorous grower. Color, white shaded with salmon; outer petals edged with bright rose ; flowers large and perfect shaped. One of the most beautiful colored roses known. 75 Cents per I $2 ; \$ 6.00$ per Ioo.

Marie Lambert-Seedling of Madame Bravy; called by some the White Agrippina, from its great freedom in bloom ; it certainly blooms as free as Hermosa. \$I.00 per I 2.

Princess de Hohenzollern-Blooms in clusters; seedling of Papa Gontier. An excellent rose. \$I.OO per I 2 .

Mad. Schwaller-A great bloomer, producing quantities of large, fine, pink blooms shaped like a Hybrid. We consider this a most excellent rose, and likely to prove fine for forcing. $\$ 1.00$ per I 2 .

Doctor Grill-Coppery-yellow, with a fawny rose reflex. We have not given this an extended test, but we think highly of it from what we have seen. \$I.00 per I 2 .

Viscountess de Wautiers-Silver rose color. A most excellent summer bedding variety. \$I.OO per I 2 .

Archduchess Marie ImmaculataPerhaps the most striking and distinct rose

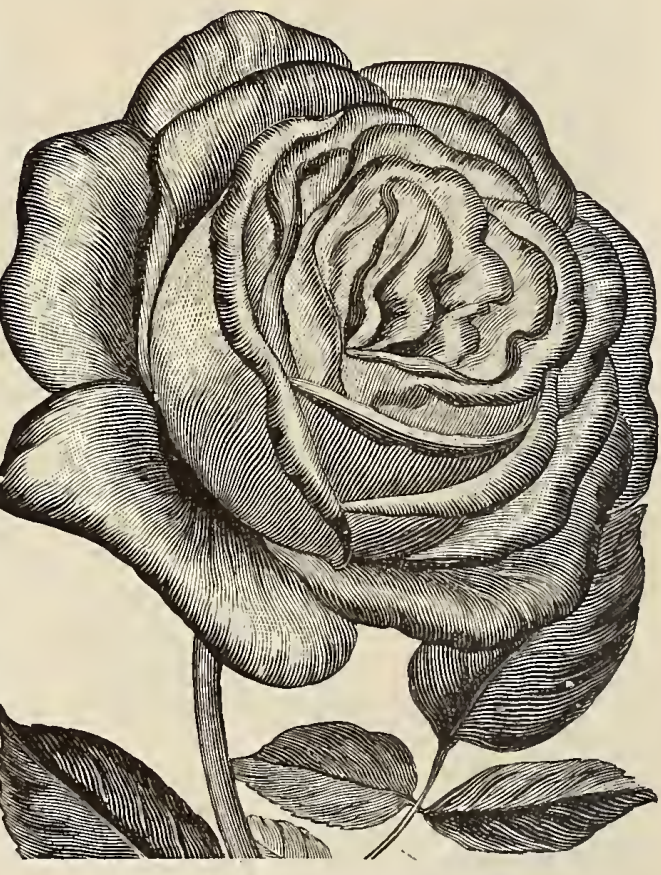

MAUAME DE WATTEVILLE. of its year ( 1887 ). We can not attempt to describe it, more than to say it is a combination of yellow, bronze, peach, and rosy crimson. \$I.OO per I 2.

Miss Ethel Brownlow (Tea).-Recommended by the raiser to be a variety of superior merit, somewhat resembling Catharine Mermet in color and shape of flower; of a good, strong robust habit. \$I.50 per I 2 .

Letty Coles - A most magnificent Rose and not as widely disseminated as it should be. A splendid grower, color soft, creamy white, with bright, rosy carmine center. \$r.00 per I 2 .

Puritan-A beautiful pure white variety of the most delicious fragrance. In size and shape of flower it very closely resembles the Hybrid Perpetual class, with the flowering habit of ever blooming section, the flower is surrounded by a wreath of foliage which sets it off to the best advantage. \$I.5O per I 2, \$10.00 per IOO. 
Perle des Jardins - Without doubt the finest yellow rose in cultivation; canary or golden yellow, flowers large and beautifully formed, handsome in every stage of development, from the smallest to thie open bud. No rose of its color ever cultivated for cut flowers up to the present time is now so valuable as this. 2 -inch pots $\$ 5.00 ; 21 / 2$ inch pots $\$ 6.00$ per 100 .

Niphetos-An elegant Tea Rose, very large and double, deliciously sweet, color, pure snow white, highly valued for its lovely buds, which are very large and pointed, and borne on long stems. This variety is extensively grown where large pure white pointed buds, are in demand. 75 Cents per I $2, \$ 5.00$ per I0o.

Sunset-This is equally as popular for forcing as Perle, the color is a remarkable shade of rich golden amber, tinted and shaded with dark ruby copper, vigorous, strong grower. 75 Cents per I $2, \$ 6.00$ per Ioo.

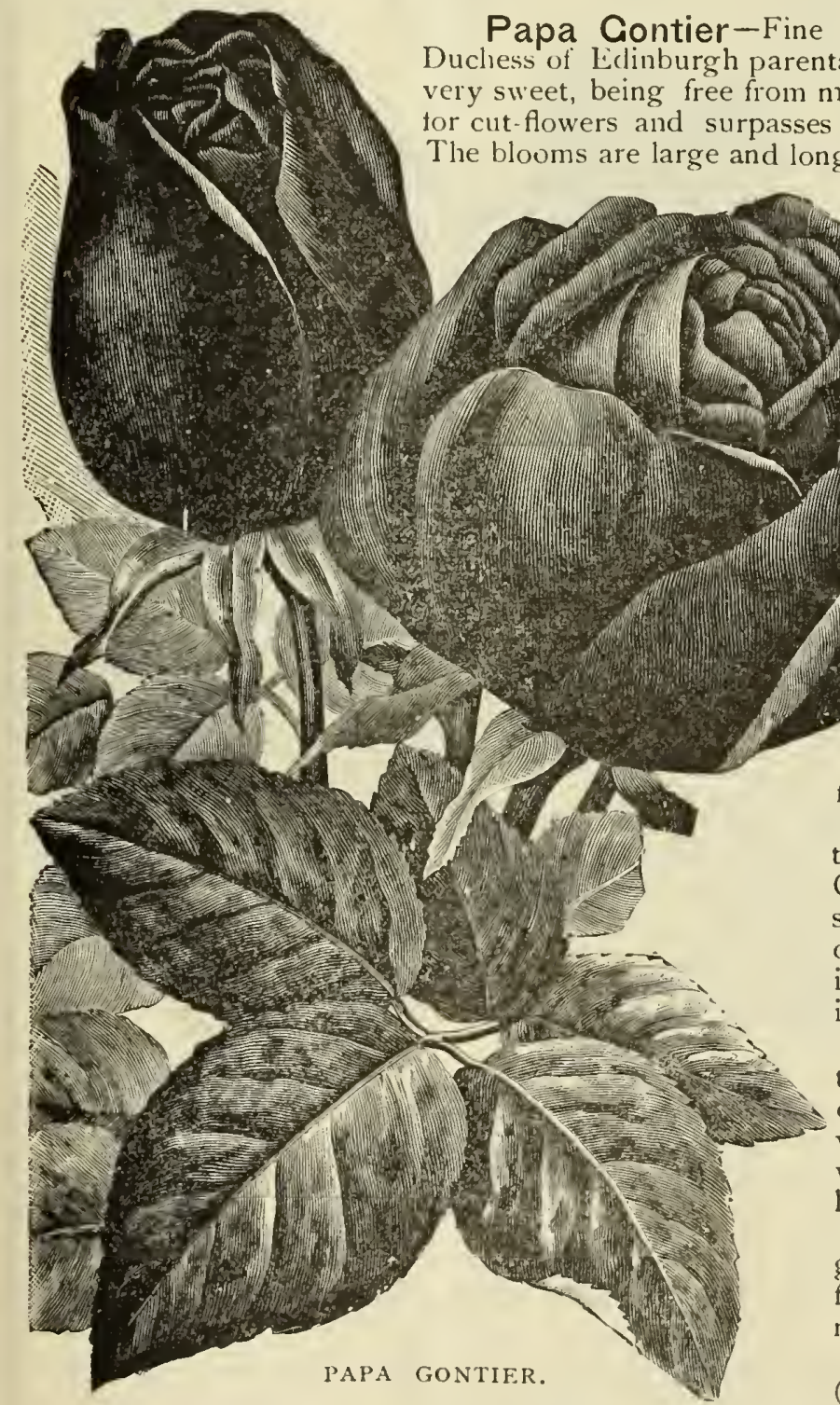

Duclea foliage, showing distinctly the very sweet, being free from nildew, it is one of the best roses for cut-flowers and surpasses Bon Silence for winter forcing. are dark carmine crimson. The inner petals are a bright rosy carmine and light up well at night. $\$ 5.00$ per 100 .

Mad. WelchAn extra fine variety; very large and double; color, apricot yellow, center shaded with dark orange red. $\$ 5.00$ per I0O.

Hermosa-A fine old rose; color, clear pink; a consis. tent bloomer. $\$ 4.00$ per IoO.

Note-Of this fine old favorite we have a fine stock of strong plants.

La France-Undoubtedly the most popular H. T. of to-day. Color, a delicate silvery rose, shaded with cerist pink, large double, and of superb form, taking the lead in its class as a forcing variety. $\$ 5.00$ per I00.

Sombrueil-This is one of the finest old Tea Roses of its class; free flowering showy and very large. Color, a creamy white tinted with rose. $\$ 5.00$ per hundred.

Susan Blanchet-An elegant bedding variety. Color, flesh salmon, shaded with salmon rose and white. A grand rose.

Souv. Therese Levet(New Red Tea Rose)--Color, clear scarlet, shading darker, flowers remain in half opened condition for a long time; will prove valuable for summer flowers. $\$ 5.00$ per hundred. 


\title{
EV W H
}

\author{
GENERAL COLLECTION.
}

Onr Stock of Roses is large and stock in fine shape; all grown in $21-2$ inch Pots. Price, 50 Cents per $12, \$ 4.00$ per 100 , Please write for estimates on larger quantities, sending list of wants.

Souv. Therese Levet-(Nerw Red Tea Rose)-Color, clear scarlet, shading darker, flowers remain in half open condition for a long time; will prove valuatile for summer flowers. $\$ 5.00$ per J 00

Susan Blanchet-An elegant bedding variety. Color, flesh salmon, shaded with salmon rose and white. A grand rose.

Marie Guillott-The Rose for the Florist. Nothing surpasses this variety for buds and open flowers. Color, pure white, extra large and double. 2 inch pots $\$ 4.00$ per IOO, $2 \mathrm{I} / 2$-inch pots $\$ 5.00$ per 100 . low.

Safrano-Bright apricot yel-

Mad. Joseph SchwartzLight salmon rose, fine form.

Mad. Margottin - Beautiful dark citron yellow, with bright center.

Cornelia Cook-Pure white; magnificent buds, perfect form.

Marechal Neil-Flowers extra large, very double and deliciously perfumed; color, deep golden yellow; buds immense size.

Duchess of Edinburg-A distinct character; a dark velvet crimson; strong grower; good foliage, fine in bud.

La Pactole-Pale sulphur yellow, large and full.

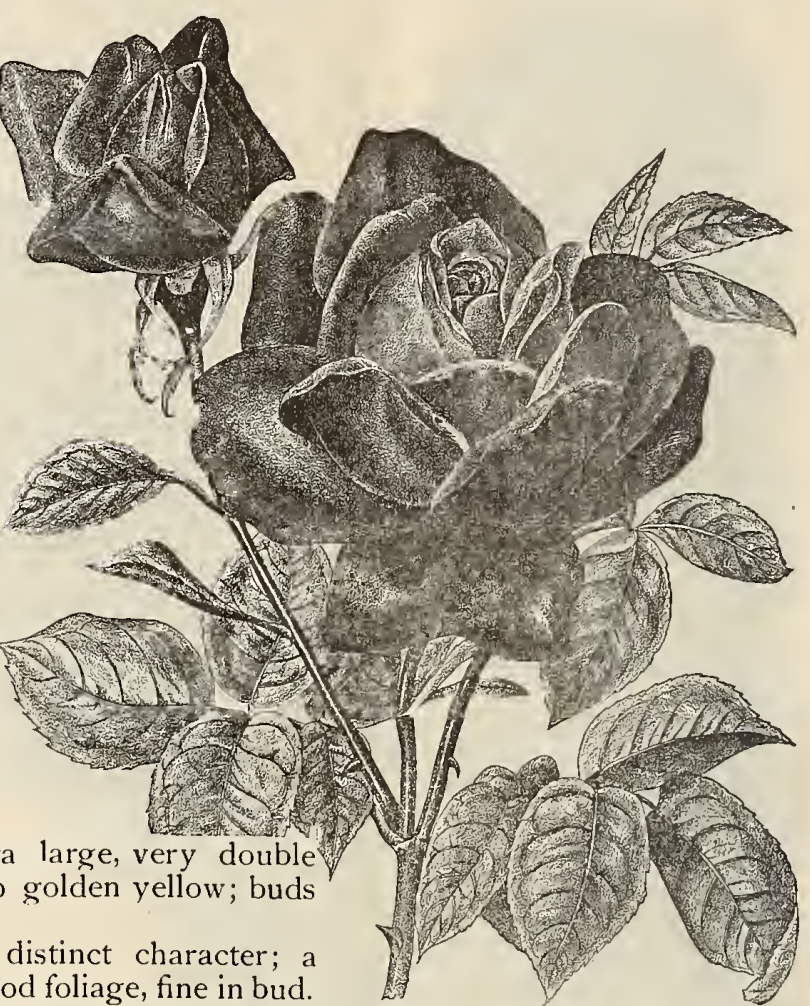

SOUV. THERESE LEVET.

Duchess de Brabrant-Soft, rosy flesh, changing to deep rose.

Isabel Sprunt-Light sulphur yellow.

Queen's Scarlet-Dazzling crimson scarlet, beautiful bud, and a very fine pot rose.

Md. Pauline Labonte - Salmon, fine bloomer, vigorous.

Madam Camille-Delicate salmon pink, a splendid rose.

Madam Lambard-Extra large, full flower. Color, a beautiful shade of rosy bronze, changing to salmon and fawn.

Md. Celine Berthod-Deep clear yellow, very double and tea scented.

Malmaison-Rich creamy flesh, with rose center, extra size; very double; one of the finest varieties grown.

Catherine Mermet-A beautiful, clear flesh color, with the silver luster seen in La France; large, tull, well formed, very beautiful in the bud.

Comtess de Labarthe-Rosy perch, shaded with amber, a fine sort.

Louis de La Rive-A gond grower; color, flesh white, of fine form. 
The Bride-This is now one of the leading white roses for winter flowering: It is of a pure white color, and possesses all the good qualities of Catherine Mermet. Such has been the demand for this rose that we have made great efforts to have a large stock.

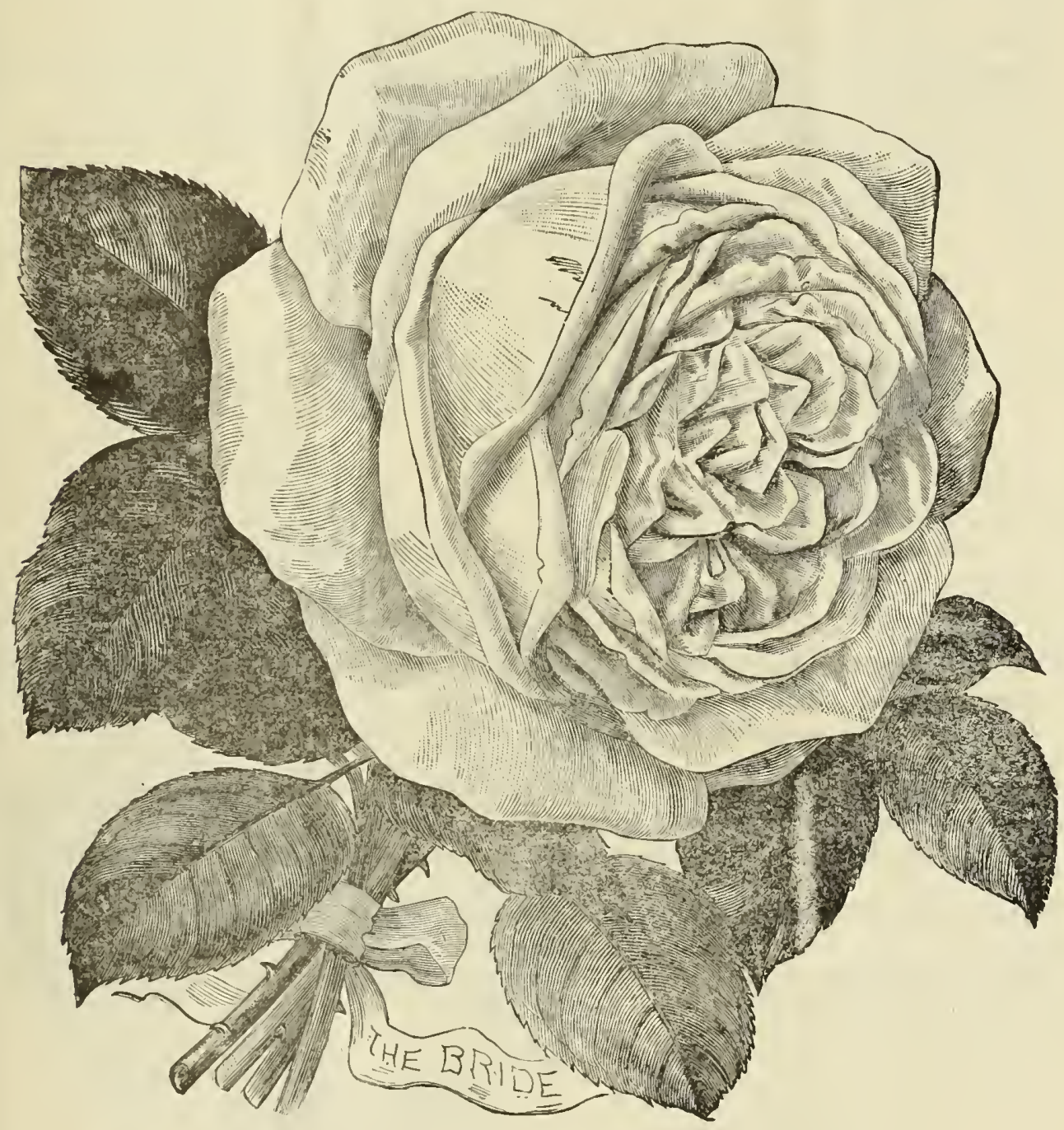

Aline Sisley - A beautiful shade of violet red; fine large pointed buds.

A d a m - Bright carmine pink, large and full ; delicious tea scent.

Arch Duke Charles-Brilliant crimson scarlet, shaded violet.

Agrippina-Fiery red, good size and form, profuse flowering.

Appoline-Delicate pink, changing to a clear rose, fine grower.

Vallee De Chamounix--Color, coppery rose ; a novel color.

Louis Richard--Coppery rose, flowers very large.

Marie Van Houtte--IVhite, slightly tinted yellow, fine for forcing.

Mad. Bravy-Rich, creamy white, with blush center; perfect form ; large, very double and sweet.

Souv. D'un Ami-Color, fine delicate rose, shaded with salmon. 
Etoil de Lyon-A magnificient rose, color brilliant chrome yellow, all opening in the center pure golden yellow. and sweet.

Marie Ducher-Rich, transparent salmon, with fawn center, large size, very_double

Souv. d' David--Rich crimson, very double, good bloomer.

Lamarque-Flowers of medium size, born in clusters, very double; color a pure white.

La Princess Vera-Creamy rose, vined lilac, large and full.

Francisca Kruger--A rich shade of copper yellow, fine form and a strong grower ; equal to "Mermet" in bud.

Mad. Lombard-Color a beautiful shade of purplish rose.

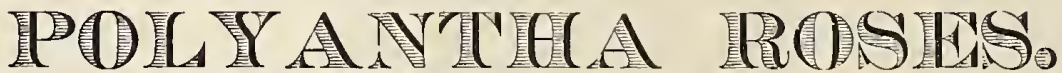

\section{Often Called Fairy Roses.}

They are quite dwarf, and are of the easiest cultivation. The foliage is very profuse, and the flowers are born above it on long stems; they bloom in clusters and are valuable for ent flowers. Fine market plants. $\$ 4.00$ per 100 .

Mignonette-Flowers full, regular and double; color, clear pink, changing to rose tinged with white, vigorous in growth, and a constant bloomer.

Mad. Cecil Bruner-Flowers salmon pink, and borne in clusters. A very beautiful little rose.

Pacquerette-The most double of all the Polyantha varieties; pure white and fine gobular form.

Mdle J. Burland-White shaded with carmine rose, of medium size, very double flowers produced constantly.

\section{HYBRID PERPETUAL ROSE.}

Gen. Jacqueminot-Brilliant crimson. We have a very large quantity of this variety, and those in need of a quantity should correspond with us. Price, strong plants in $21 / 2$ standard pots $\$ 5.00$ per Ioo.

\section{HARDY CLIMBING ROSES.}

P. Queen, B. Bell and Seven Sisters-50 Cents per I2, \$4.00 per Ioo. 


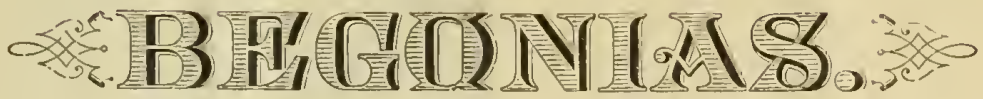

\section{BEST NEW AND OLD VARIETIES.}

The following are the finest additions of recent years to the Begonia family, all bearing a profusion of large pink flowers.

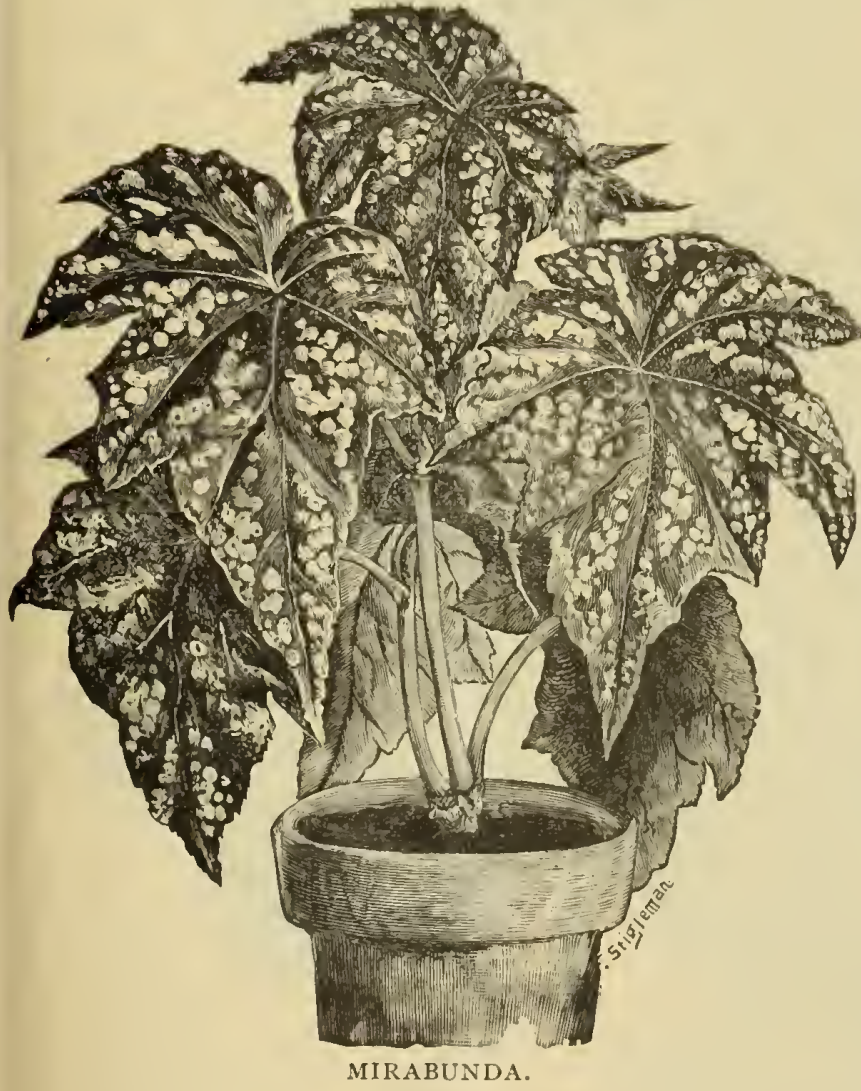

Mme. Lipnnet - Ribs are lined with bands of the darkest myrtle green; body of the leaf a brilliant rosy bronze; the surface entirely covered with crim. son pile; the leaf is elegantly pointed and measures about 6 by Io inches.

Pres. Bouerville - Dark brown green, surface with depressed veins, the surface closely dotted with crimson pile. Each pile rising from a small silvery dot. The leat of fine shape and exceedingly brilliant.

M. Hardy-Darkest bronze, nearly black; as glossy as if lacquered; sunk veins of bright red; profuse crimson velvet pile over the entire leaf; exceedingly fine.

Glorie de Juoy-The lightest of the four. Color, a pale bronze green with green pile. Each 50 Cents, the set of four varieties for \$I.5O.

NotE-The above are the most striking varieties of this interesting family.

Mirabunda--This is one of the most beautiful Begonias of all the new Begonias, and is the result of crossing $B$. Diadema with the Rex. It is an elegant pot plant; thrives and grows with grace and ease of the new Begonias of the year. It has large nicely shaped leaves, of a rich clear green, marked with large silver dots and splashes. Each 3.5 Cents, $\$ 3.00$ per I 2 . 
Diadema-A distinct and comparative new variety; color of leaf rich olive green, handsomely spotted with silver, large foliage. Each 20 Cents, \$2.00 per I 2.

Begonia Decora-A shrubby decorative variety, with dark green obliquely lanceolate leaves, profusely marked with oblong spots or dots of a silvery-grey color ; somewhat of the character of Begonia Argyrostigma, but with the spots more minute. It has been introduced from Brazil. 20 Cents each; $\$ 2.00$ per dozen.

Begonia Compta-A pretty ornamental species from Brazil. Its leaves have palish pink footstalks, which are five to six inches long, remarkable for the unequal -development of their two halves, the one side being narrowed to the base, and the other developed into a roundish angular lobe. The color is satiny green with a silvery tinge along the course of the mid-rib; this coloration with the satiny surface being of a very pleasing character. 20 Cents each; $\$ 2.00$ per dozen.
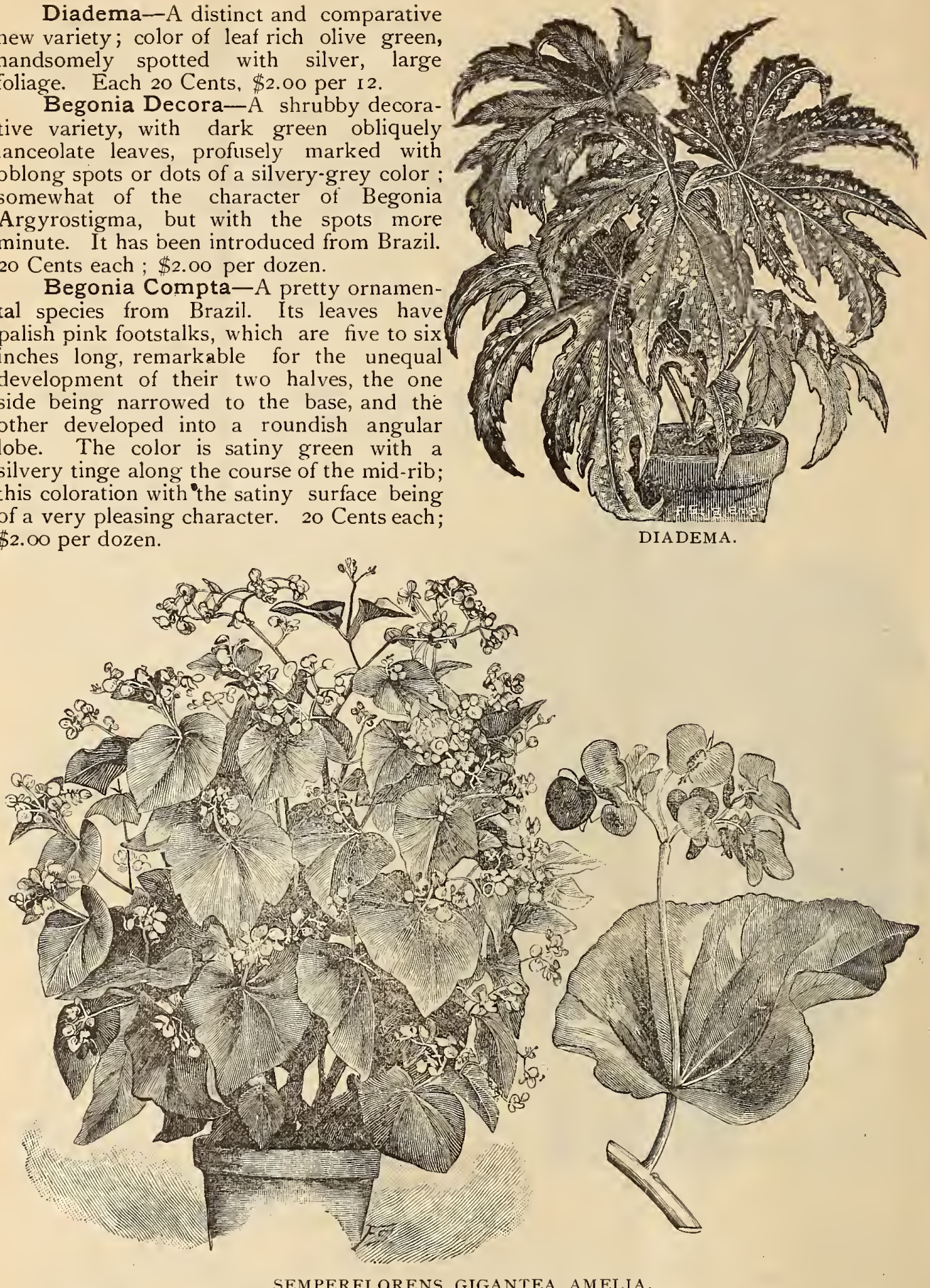

Semperflorens Gigantea Amelia-This wonderful free growing Begonia of sterling worth and great beauty. This has the habit of frequently blooming at the junction of the ribs 
of the leaf, and it imparts a novel appearance when exhibiting this peculiar character; a compact grower ; flowers a carmine rose, produced in greatest abundance in winter and spring months. 25 Cents each; $\$ 2.00$ per dozen.

Glorie de Sceaux-One of the finest flowering Begonias introduced for many years. It is of upright habit, producing during the entire winter large flowers of a soft, clear pink, contrasting well with the rich plum foliage of the size and shape of the Rex. A good thing. Each 25 Cents; $\$ 2.50$ per 12 .

Begonia Argentia Guttata-This variety is introduced by Lemoine and is a cross between Olbia and Alba Picta. This beautiful sort has the silvery spots of A Picta and the grace and beauty of growth of Olbia ; its purple bronze leaves are oblong in shape, with large silvery blotches. We can specially recommend it. Each, 5o Cents.

Manic a ta Aurea-This cut is a true representation of $\mathrm{th}$ is $\mathrm{gr}$ a n d variegated Begonia. Its he avy glossy leaves being boldly blotched with a rich golden cream, and a clear carmine etching in the matured leaves; altogether making the handsomest variegated plant known. It is equally as strong in growth as Manicata. 35 Cents each, $\$ 4.00$ per 12.

Semperflorens
Gigantea Ele-
gans-This fine new variety attains a height of twelve to fourteen inches, and is a compact mass of medium sized, glossy, olive green leaves. It blooms continuously and is so free as to present the appearance of a huge bouquet. The flowers are a rosy flesh color, and are raised well above the foliage on strong foot stems. We believe the above is the finest flowering Begonia yet introduced. 20 Cents each, $\$ 2.00$ per I 2.

NotE-The above is a variety of great merit and should be better disseminated. 


\section{BEGONIA OIBIA.}

A late introduction and still quite scarce and altogether a grand variety ; the leaves are from seven to ten inches in diameter, and are separated into deep sharp points ; the color is varying shades of brown and red, the young leaves having large silver blotches and are very bright and attractive, the arrangement of the veins gives the leaf an uneven surface. This variety soon attains a heavy main trunk, which carries the branches in erect form, making one of the finest decorating varieties we have; flowers very large and of a crystal white. Each 35 Cents ; $\$ 4.00$ per I 2.

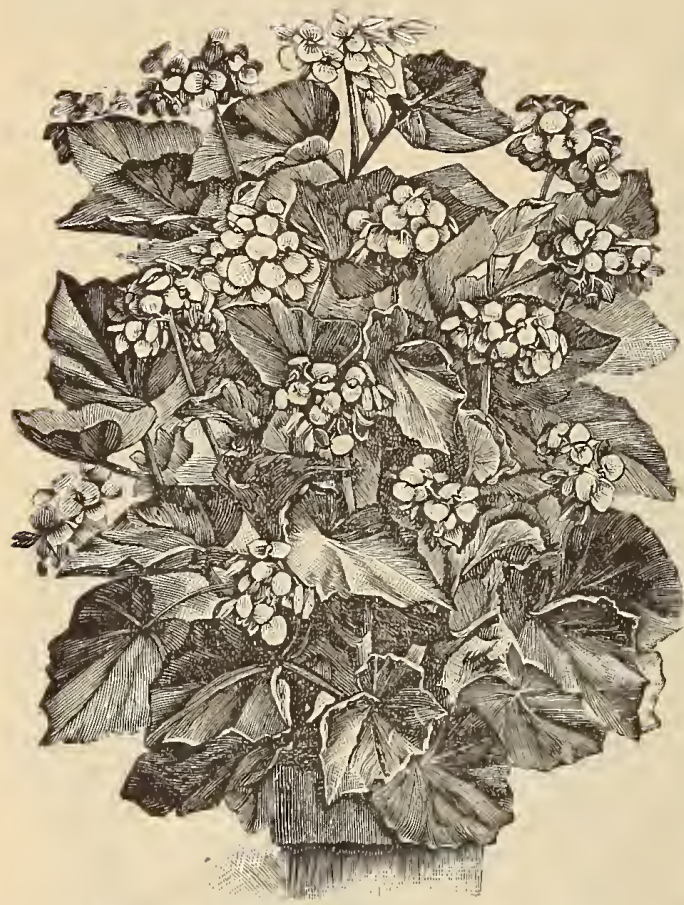

Semperflorens Gigantea RoseaThis is one of the finest Begonias of recent introduction, and is destined to become popular as a pot plant and for cut flowers. Plant is a strong grower; round and bushy in form; flowers are borne in large open panicles; borne well above the foliage, on strong foot stalks, of a bright carmine color ; blooms from October to June. A grand market variety. Sells at sight. Try it.

Rubella-A very ornamental Indian species, belonging to the Ricinifolia section. Leaves irregular, blotched, red on a pallid ground, ribs banded with purplish brown, under surface red. 3-inch pots, \$I.Oo per dozen ; $21 / 2$-inch pots, $\$ 5.00$ per hundred.

Tueschei-A very fine growing ornamental Begonia, with red colored flowers. Io Cents each; $\$ 1.00$ per dozen.

Bruantii-Foliage very bright green, quite large, pure white flowers, borne in great profusion; should be grown in large quantities for cut flower work. 50 Cents per 12.

Bruantii Rosea-A stronger grower than Bruantii, and is a compact mass of medium sized, glossy, green leaves, very free and quite large ; flowers white in center, margined with delicate pink. 50 Cents per 12.

SEMPERFLORENS GIGANTEA ROSEA.

Dr. Nachtigal-Flowers a tender rose color and very odorous ; the only fragrant
onia that we know. It has large deep green leaves, and is a strong vigorous free flowerBegonia that we know. It has large deep green leaves, and is
ing variety, of upright growth; Very pretty. 25 Cents each.

$\mathrm{Hy}$. Coccinea - In foliage and habit quite similar to our old favorite Weltoniensis, but in place of the soft pink flower of that variety, this bears the greatest profusion of cardinal red blooms, with the brush of quivering yellow stamens forming a beautiful center. One of the best. Color especially fine. \$1.00 per dozen. dozen.

Manicata-Large, plain green foliage, pink flowers. 3-inch stock plants, 75 Cents per

Margaritæ-A variety with leaves like Metallica, to which it is related. It grows in round, bushy form ; leaves bronze-green, with purplish cast. Very free flowering. Large trusses of delicate cream and rose-colored flowers. Io Cents each ; \$I.0O per dozen.

Moonlight-A dwarf, bushy variety of the Weltoniensis type, foliage light green, flowers pure white, very large and borne in great profusion. A fine variety. Io Cents each; 75 Cents per I 2.

McBethii-A new hybrid, fine cut foliage, always in flower. Io Cents each ; 50 Cents per dozen.

Weltoniensis-Flowers very abundant, pink. Io Cents each ; 50 Cents per dozen. 
Alba Picta - A distinct new variety. It is shrubby in habit and of compact form, having long slender lance shaped leaves on short stems; thickly spotted with sil. very white; the spot graduating in size from the center toward the margin; foliage small and the branches are upright and gracefully curving. A fine pot and decorating plant. Altogether, one of the best, and destined to become popular. 50 Cents per $12 ; \$ 4.00$ per 100.

\section{Sunderbruchii -} In habit like Ricinifolia, foliage not quite solarge, the leaves are separated into nine sharp points, surface bright metallic green with veins marked and broadly shaded with velvety black. It bears large panicles of pink flowers. Each 15 Cents; $\$ 1.50$ per 12.

Metallica - This elegant variety has very large glossy leaves, shaded with green crimson and olive, with a peculiar metalic luster over all, flowers a clear pink shaded white; a grand pot plant for market; $\$ 5.00$ per 100 .

Rubra As a mar. ket plant it has no superior. Its wax like scarlet flowers and rich green leaves makes it
one of the most salable plants we know of. Strong Plants. 50 Cents per 12; \$4.00 per roo.

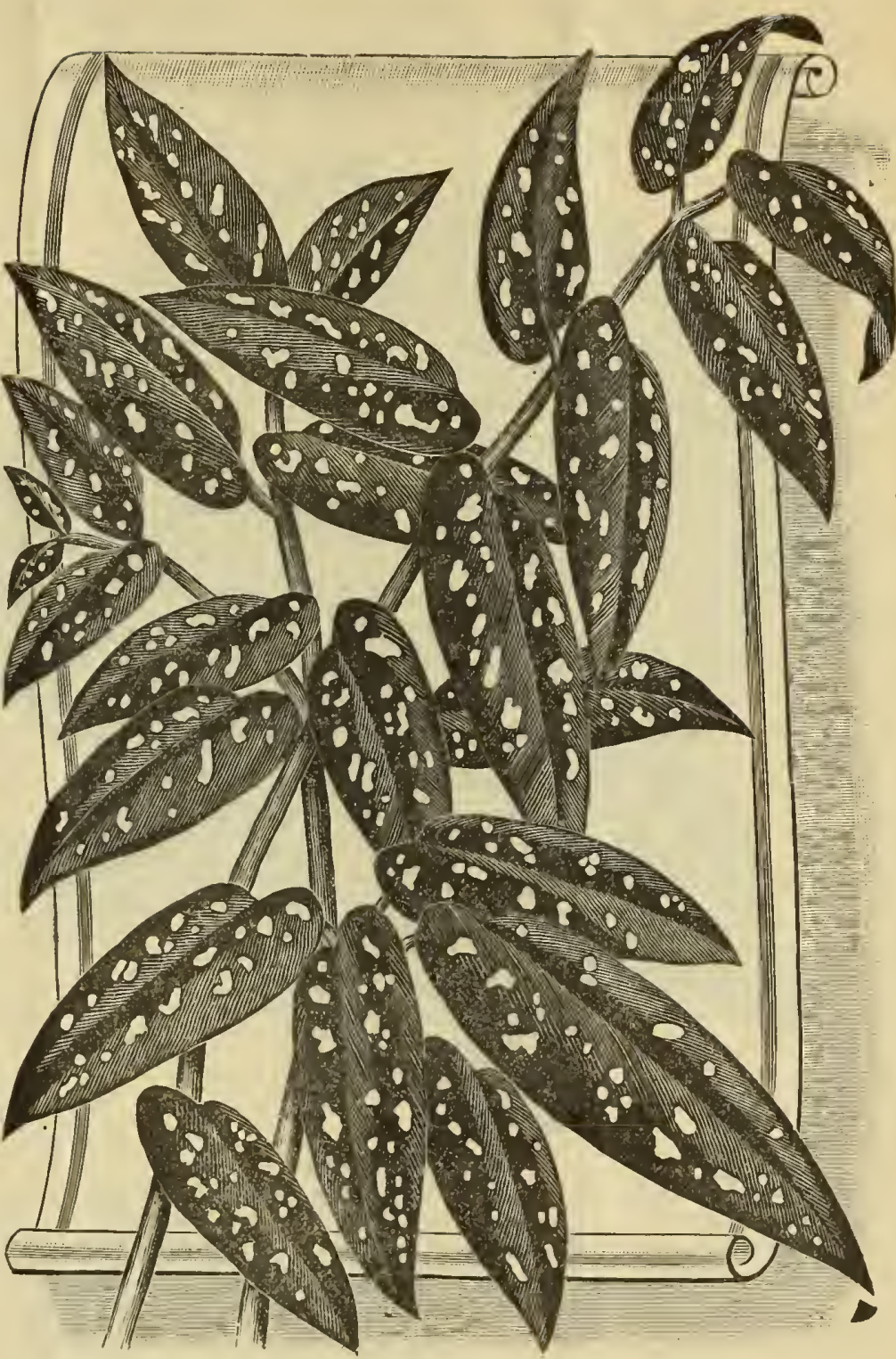

Ricinifolia-So called from its likeness to the Ricinus, or castor-oil plant. The leaf is very large - will average a foot or more in diameter-and is separated into seven or nine large points, carried on thick, heavy stens, eighteen inches or more in height ; color a rich green, with redish markings; surface velvety. In bloom it is magnificent; the panicle, composed of great numbers of individual pink blooms, is lifted high and spray-like, quite clear of the foliage. One of the hest for winter bloom, besides being ornamental in foliage. Price $\$$ I.00 per dozen.

Argyrostigma Picta - A handsome, compact growing variety. Leaves smooth and glossy, a silvery green, dotted white, and the shape and size of the leaves of Rubra. Flowers lemon white, produced in corymbs. A magnificent pot plant. Price 75 Cents per dozen. 


\section{NEW REX BEGONIAS.}

Queen Victoria-Solid silver leaf, of crepe like texture, reddish vines, embroidered margin and fluted redish edge. Each ro Cents ; 75 Cents per I $2 ; \$ 5.00$ per Ioo.

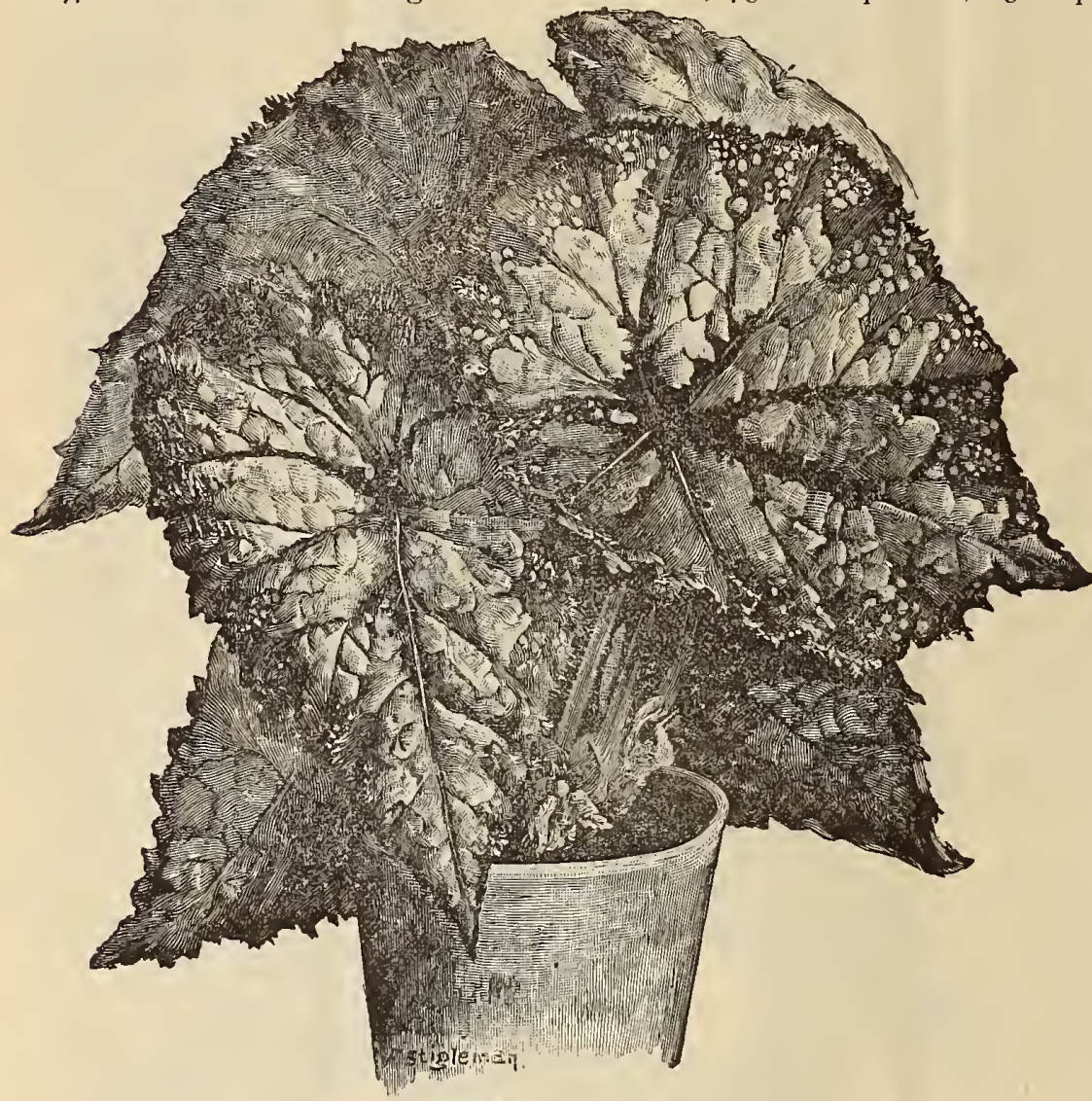

LucyClosson-- One of the richest and most beautiful of the Rex family; this is a seedling from LouisChretien with larger leaves and much stronger growth; the coloring of $\mathrm{t} h \mathrm{e}$ leaves is simply magnificent, be ing heightened by an intense rose red color, margined with olive green and spotted with silver. Each, 50 Cents.

Lesondsii -This is $t h e$ largest and finest leaved of any of this family; it is a cross between B Diademi and the R.ex, but retains i n a marked degree the Rex character. 25

QUEEN VICTORIA. Cents each.

Count Louis Erdody--This is the Begonia of all Begonias, and a plant of unusual beauty, peculiar and of strong growth; it originated from seed from Begonia Alexander Von Humboldt, hybridized with Begonia Argentea Cupreata, by the gardener of Count Erdody, a Hungarian nobleman. The leaf, which has a metallic luster, appears dark silvery in the center, shading into coppery rose toward the margin, which is broadly and evenly edged with the same hue, but darker and more brilliant; the veins are yellowish green on both sides, accompanied by a dark green ribbon, white, owing to an elegant undulation of the leaf; they run in a sort of groove close to the margin of the leaf. The striking peculiarity, however, which distinguishes it from all other Begonias consist in the fact that the two lobes' at the base of the leaf do not grow side by side, but one of them winds in a spiral like way until in full growth leaves; there are four of these twists lying on top of the leaf nearly two inches high. This is truly an interesting curiously handsome variety. This variety retains the general character of the Rex family as to growth, but is so distinct in growth and peculiar leaf formation that it stands out unique and striking in all its individual beauty, having a good. stock we are able to place this novelty within the reach of all. Each 25 Cents; \$2.00 per I2; $\$ 12.00$ per IOO.

Mad. Treve-A hybrid Rex of upright growth, attaining a height of two feet. This will become very popular as a pot plant. 75 Cents per I $2 ; \$ 5.00$ per Ioo.

Rex Begonias in a good assortment, named varieties, at ro Cents each; 75 per I 2 ; $\$ 5.00$ per 100 . 
Wm. Swayne-New White Carnation. This new variety, the result of a cross between Peter Henderson and Snowdon, has produced just what is needed, a strong free grower; early, continuous bloomer; flowers very large and full, heavy texture which renders it very valuable for long shipping purposes. Very fragrant and grows a large proportion on long stems. The habit of plant is stronger than Henderson. which it resembles. Altogether the finest white Carnation grown. Io Cents each ; \$I.00 per I 2 ; \$8.00 per Ioo.

M'lle Carle (French) -One of the best white Carnations Color and form superb, in size like a small Camelia, which it also resembles in heavy waxy texture. 50 Cents per dozen : \$4.oo per roo.

American Wonder (New.)-A good market variety, soft rosy carmine. 5o Cents per dozen : \$4.oo per hundred.

Philadelphia (Striped.)-Color, white ground, with clear cardinal striping, very free, of strong growth. 40 Cents per dozen; $\$ 3.00$ per hundred.

J. Perkins-Plant very vigorous, of fine branching habit. Color, pure soft rose, healthy and free flowering. 50 Cents per dozen ; \$ 4 .00 per hundred.

Gambetta - A strong robust grower, flowers large and full, of a rich orange color, blotched and flaked with carmine. 50 Cents per dozen ; \$3.00 per Ioo.

Buttercup-One of the finest varieties of recent introduction. Color, a rich yellow with clear carmine streaks, strong rubust grower. Io Cents each ; 75 Cents per dozen; $\$ 5.00$ per 100 .

Sunrise-A strong vigorous grower of good habit. Color, light buff, flaked with bright carmine, flowers very large, of good shape, fragrant, free and do not burst, altogether a grand variety for pot culture. $\$ 3.00$ per hundred.

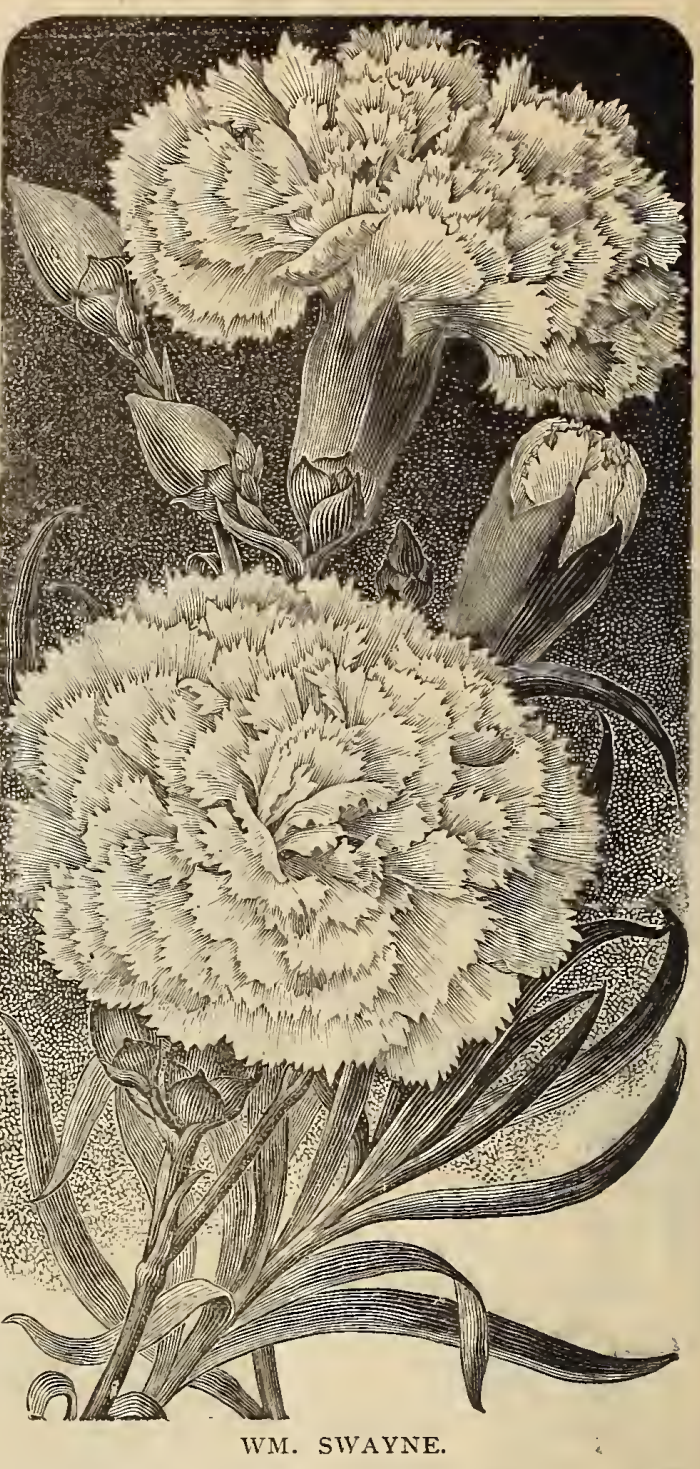

Portia-The finest scarlet and most productive of its class. Strong grower, free bloomer, an excellent market sort. 40 Cents per dozen; \$3.00 per hundred.

Grace Wilder-Clear pink, long stemmed flowers, thrifty and constant bloomer. Selling for more money than any other variety, bringing $\$ 5.00$ per hundred at Christmas, wholesale. 50 Cents per dozen; \$4.00 per hundred.

Peter Henderson-Large pure white, of perfect form. 40 Cents per dozen ; \$3.00 per IOO.

Mrs. Cleveland (New.)-A deeper shade than "Grace Wilder," of strong habil, frèe flowering, and all together a fine Carnation. 75 Cents per dozen; $\$ 5.00$ per roo.

Sensation--A strong, robust grower, flower a light sulphur color, with rich pink flaking, one of the best for summer flowering. 5o Cents per dozen; $\$ 4.00$ per roo.

The Century-Rich, glowing carmine, early and free blooming variety. The best of its color. 50 Cents per dozen; $\$ 4.00$ per roo.

La Purite-Old standard, and still very thrifty with us. Color, bright rosy carmine, $\$ 3.00$ per hundred. 
E. G. Hill (Thorp)-This is the very best Carnation for cut Alower purposes ever introduced. Early flower, with long stems and never bursts, color deep velvety red, size large and full with fringed edges, and an exceedingly strong grower; 50 Cents per 12, $\$ 4.00$ per IOO.

W. W. Coles-Plant dwarf and bushy in growth, perfectly formed flowers never burst, very prolific, on long stems. Color, a fiery bright scarlet, unequaled by any other Carnation: 50 Cents per I $2, \$ 4.00$ per 100 .

Henzie's White-One of the most desirable white Carnations for winter flowering, never burst the calyx; large flowers of perfect shape. A continuous bloomer; $\$ 3.00$ per roo.

President Garfield - A very robust, strong growing Carnation, very bushy, however. Color, a deep rich scarlet-crimson or blood-crimson, ends of petals twirled in shell-like fashion. The flowers are produced in great profusion; $\$ 3.00$ per 100 .

Anna Webb-A fine crimson deeply fringed, medium size, branching habit, very free and continuous bloomer. I consider it far ahead of Crimson King; 50 Cents per $12 \$ 4.00$ per IOO.

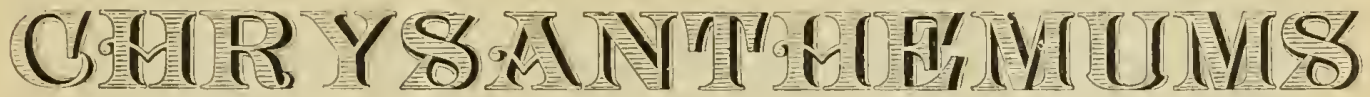

Chrysanthemmus are now and deservedly so the most popular Antumn Flowers. 'Their fasy culture, gorgeons color's and fantastic shapes of many of the varieties, make them the

flower of fashion, and we predict that the day is fast eoming when we will have

"Chrisanthemum Exhibitinos" in every city and village in the comntry.

We wisl to say to onr enstomer's that our stock embralces all of the worthy varieties of to-day, and having ordered large-

Iy of the novelties of this year. can fill orders for them at the disseminators price.

\section{NEW FRENCH VARIETIES.}

Anna M. Payne-Very large long twisted petals; an immense irregular plumy flower of white, touched with clear lavender; center pale yellow of short petals in whorl.

Belle Pointvine (Early)-Large spherical snow white; the most regular and perfect incurved; a grand variety, though regular very soft in outline.

Bettine-Beautiful clear bronze, incurved large flowers of long petals; reverse silvery.

Benoit Rozain-Beautiful satin rose color; flowers very large, with large concave petals. One of the best rosy pinks.

Capucine-Center brownish yellow, incurved; a very large half globe. Very soft and "fluffy."

Cythere-Bright rosy violet ; immense flower ; in ball shape, and of even coloring.

Delie-Cord-shaped petals of old gold, just touched with Siennese red; forms an almost perfect ball of great size ; an extra beautiful variety in this color.

Emile Belloc-Delicate long petals, finely striped in amaranth and white. A plant in full bloom is covered with a veil of rose color.

Fee Melusine-Very odd and beautiful ; the petals rise like rays, long, slender, and straight ; center of petal white, edged carmine.

Fred Harte-On opening is irregularly incurved, gradually becoming recurved; color rosy lilac, turning to white in the center. 
Gustave Madand-A grand variety, long creamy white petals of heavy cord, shape rising regularly to form a $3 / 4$ ball.

Harman Payne-Flowers very large with long petals; color bright rose reverse of petals a paler shade.

Livadia-An improved "Timbal d'Argent ;" larger and not so compact, having a softer appearance, and bringing fewer imperfect flowers.

La Tosca-Bright red, with amber shadings; center golden yellow. A gorgeous plant in the sunlight, though the individual flowers not very large.

Mazicienne-Fine orange buff, largest size, petals spathed with bud like center ; very fine ; color very striking. Early.

Mme C. Audigive-One of the finest Pinks ; large, soft and feathery ; slightly recurved, but irregular. A magnificent variety.

M. Pierre Destombes-Petals 3 to 4 inches long ; entirely tubular ; soft rosy pink tinted saffron at the center. After the general shape of Mrs. Cleveland; does not show the dark receptacle as that variety does.

Mme. Lay-Soft pink, lighter center, very large and informed, upright petals, half spherical. Extra fine

M. Castex-Very large anemone flower, of a pure even lilac. A pretty variety.

M. Phatzer-Tubular petals, with very prominent spathe ; outside of tubes pale pink, showing a pure white lining.

M. Louis Langlois-Petals half tubular, golden yellow, and brownish red; when . fully expanded, the tubes open, and are convexed and arranged in immense turbine form.

Nelson-(Originated in England.) Immense flat anemone form ; 5 to 6 inches in diameter even on small plants ; color odd shade of ashes of roses and fawn pink ; a peculiar variety.

Sabine-Sott canary yellow, of exactly the form of Timbal d'Argent; that is, a medium-sized anemone; very beautiful.

Sec. Barrett-Chamois, and red and gold, of needle shape, with yellow center ; very soft and informal. (Early, Oct. 20.) Petals upright and twisted.

Each 25 Cents; the set of 24 varieties for $\$ 5.00$.

\section{PHILADELPHIA PRIZE SET OF I887.}

Mme. Drexel-A large Japanese variety in the general style of Mrs. Frank Thompson; the flower is more incurved and the habit more compact. Of vigorous growth, and a free bloomer. Outside of petal silvery white, inside bright pink at the tips, shading to white at the center. Holds finely in bloom, and lasts well when cut.

Mrs. E. W. Clark-Splendid, good size, of extra fine form. Deep amaranth purple, reflex silvery rose. Une of the finest varieties extant. Special premium at Indianapolis show. Special prize at Philadelphia.

Mrs. Isaac C. Price-A lovely yellow, bright as gold; bloom very large, petals long and slender, arranged in a whorl while still incurved. Not at all like any other yellow. A magnificent pot variety of the most delicate feathery appearance.

Mrs. M. J. Thomas-One of the purest white, without shade or stain. Incurved so that no center shows, the petals are very broad, of the heaiest texture, ind tightly incurved; a massive flower of great size and substance.

Mrs. J. N. May-Exactly like Mrs. Thomas, except in color, which is a soft clear yellow; these two are fine companionpieces, flowering at the same time.

Mrs. A. Blanc-Center of floret erect; outer petals horizontal or drooping, of rosy lavender, center soft clear rose, with a touch of gold in center. An exquisite rosy flower. Good grower.

Lord Mayor (Early)-Carmine violet, white ground, shaded rose; dwarf and free; a profuse bloomer, opening last week in September; one of the best for pot culture. 


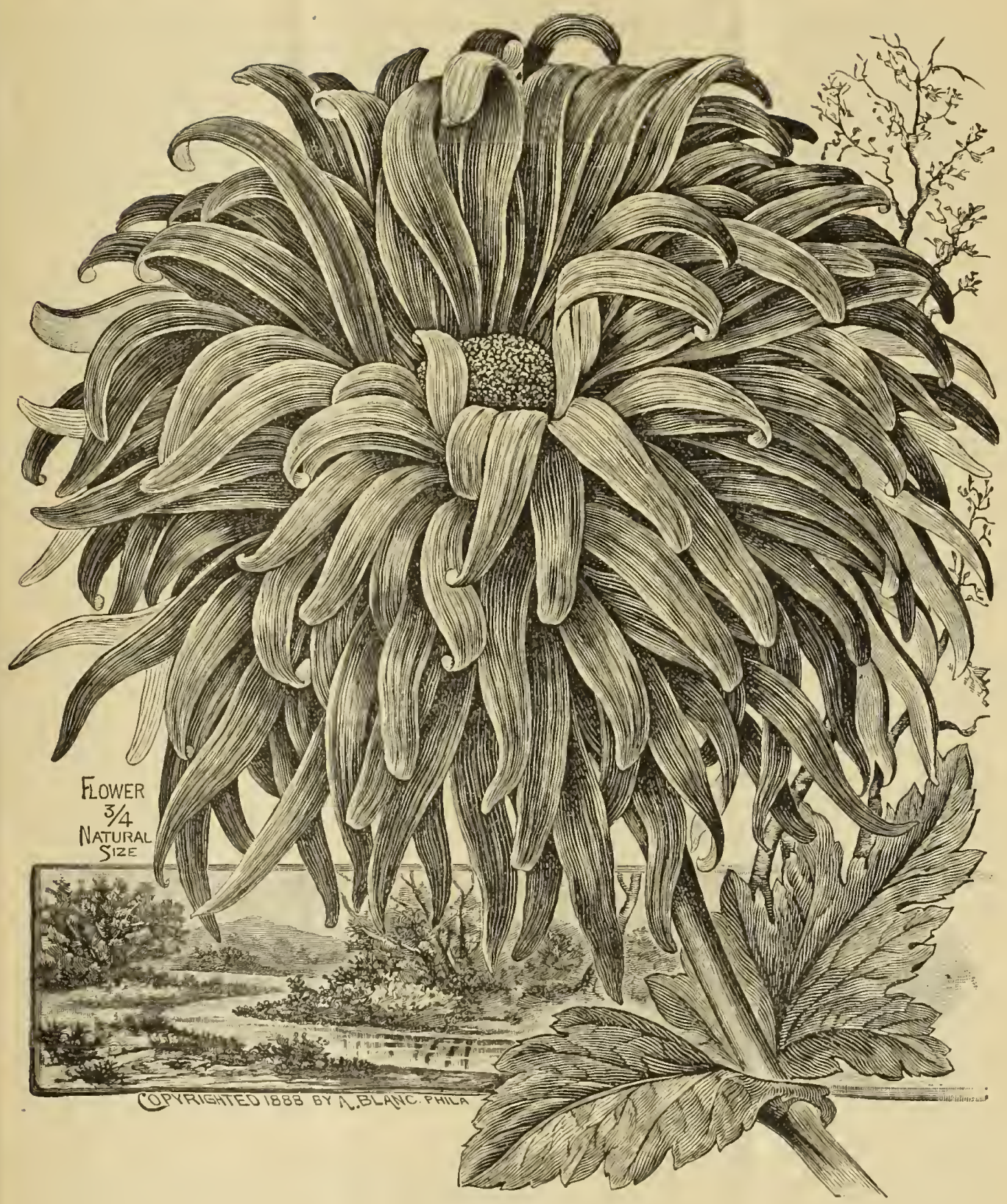

WAI.TER W: COLES.

Walter W. Coles-Very bright reddish terra-cotta, reverse pale yellow; outer petals broad, long, pointed and horizontal: center short petals, bright gold folded into pointed thread, and whorled. A very large flower, and exquisitely beautiful.

Mrs. Anthony Wiegand-Beautiful rich pink. A decided improvement in this line of color. Form excellent; producing flowers in great abundance.

L. Canning-A most exquisite white, absolutely pure; the flower is quite regular in form, very large and flat, the length of petals graduating to the center. A little later than Puritan, to which it is a grand successor. Reminds one of a large satin rosette. 
Mrs. Richard Elliott-Another grand yellow, in every way distinct from Mrs. Price and Mrs May. The form is regular, very double, showing no center, very large, and slightly recurved; petals long, and of medium width. A grand exhibition variety.

Magnet-An immense drooping flower of reddish heliotrope color. One of the most generally admired in the collection. Form, an irregular flat shape.

Mrs. Howells - A very fine red and gold variety; outer petals broad and velvety, and reflexed; inner petals incurved, forming a round golden ball. Very brilliant. A fine show variety.

Each 20 Cents; the set of 12 varieties for $\$ 2.00$.

\section{NEW AND SELECTED VARIETIES.}

G. F. Moseman-By far the finest of all varieties yet imported; nine inches in diameter, irregular, incurved petals ; buff without and bright red within; flowers large and of robust habit. Always a prize winner.

Cold-As name denotes, this is of the clearest golden yellow, perfectly double. One of the best new yellows; stock limited.

George Maclure-Nine inches in diameter, purple shaded amaranth, outer petals tubular, inner ones broad, flat and incurved; one of the largest of its class. Awarded three certificates.

Mrs. Langtry - A perfectly formed flat flower, of unusual size and perfection. Snow white in color, with broad bands of ribbon petals. Altogether one of the very finest white varieties. Very valuable, being one of the latest to bloom.

Dr. Metzger-Seven inches in diameter; clear golden yellow, reverse of petals lightly penciled brown; a little more than semi-double, with yellow daisy center ; beautiful foliage; a fine, showy plant. A first premium at Philadelphia, I887.

Thos. Cartledge-A magnificent variety, distinct orange color, of enormous size, incurving covering center and forming a ball, superior to either Comte de Germany or Mrs. Wheeler; one of the best for cut blooms.

Peter the Great-A most showy, bright lemon yellow variety, with beautiful foliage and of fine habit.

Robt. Bottomley-A grand mid-season white variety, surpassing Moonlight in size and substance ; this we consider one of the best whites.

Gloriosum-Very light lemon, with immense flowers, having narrow petals most gracefully curved and twisted; well merits its name, and is one of the most attractive varieties.

John Torpe-Eight inches in diameter, full flowers, long broad petals except under row, which contains a few tubular ones ; color richest deep lake ; a new shade. Very early and a vigorous grower.

David B. Hill-Enormous flower of beautiful canary color; petals long, flat at the end, but quilled at the base. A fine yellow.

Minnie Palmer-One of the finest whites, solid and of large size, perfectly double, incurving, style of Moonlight, on which it is a great improvement.

Lucrece--Pure white, resembling Christmas Eve, but surpassing that in size, form and lateness. Largely used for cutting and late decorations.

Mrs. T. H. Spaulding - An imnense pure white, with the broadest of petals; very long, twisting and benaing toward the center ; a good keeper, and grand variety for any purpose. Three first-class certificates.

Mrs.J. N. Gerard-A grand and beautiful cup shaped variety, closely incurving with age; of large size, and the brightest and clearest peach pink ; the finest pink ever offered to the trade.

Mont Blanc-Extra large, late, white variety; inner petals incurving, on strong, erect, foot stalks; one of the most valuable late bloomers.

Le Tonkin-Very large, fine, silvery pink; white ground; edged rose; good habit. First-class certificate. 
J. C. Blaine-Rich, dark, maroon; incurved, under side of petals tipped with old gold, flowers un long stems; very large, double, and perfect in form.

Mrs. A. Waterer-Petals from 1 to $\mathrm{I} 1 / 2$ inches wide; very late; color pure white, sometines showing a blush shade. One of the very largest.

Boule de Neige-Immense spherical balls of purest white. A most beautiful white. Splendid for pot culture.

Mrs. Frank Thompson-A silvery pink, often comes a deep carmine pink. One of the largest and best.

Mrs. Geo. Bullock-Broad petals, large flowers. A splendid white variety. Excellent for specimens.

Mrs. C. H. Wheeler-Petals bright orange, under side of petals blood red. You cannot do without this.

Montplaisant-Cramoisy red, center of the flower shading to golden yellow.

M. Buyer-Silver rose color, shading to satin pink. A flat shoe-lace petal. Exquisitely beautiful.

Puritan-One of the very finest varieties extant. Silvery white. Should be in every collection.

Wm. Singerly-Rich plum purple flowers. A verv excellent sort. Makes a splendid standard.

The above set for $\$ 3.00, \$ 10.00$ per Ioo.

\section{GENERAL LIST.}

Christmas Eve-A very useful white; we esteem Minnie Palmer much the best of the two, however.

Chas. Delmas - Bright brick-red, silvery shadings.

Diana-Very useful for cut flower work. Pure white, of medium size.

Duchess-Rich deep red, shaded and suffused with yellow.

Dr. Hogg-Violet crimson. Very distinct and showy.

Flambeau Toulousain-A very pretty pompon. Lavender in color, with lighter shadings.

Frank Wilcox-Chrome yellow, shaded with amber. Medium sized flower. Useful.

F. L. Harris-Bright cinnamon red. A distinct and beautiful color.

Golden Prince-A beautiful golden yellow. Perfectly hardy.

Grand Mogul-Violet amaranth, lined with white.

Jennie Y. Murkland-Rich golden yellow, shaded apricot.

Lord Byron-Rich orange, tipped red. Whorled petals.

Leda-Light pink, recurved. Petals twisted, with cut edges.

M. Neville-Light rosy salmon, suffused with cream. Very early and valuable.

Norman Davis-Rosy carmine, with lilac shadings. Very early and valuable on this account.

M. Freeman-Clear lavender pink. Cord-like petals.

Moonlight-Pure white. Late and useful.

Mrs Cleveland-Needle-shaped petals. Pure white.

Mrs. Mary Morgan-A perfectly formed flower. Light creamy pink, delicately shaded rose.

Osiris-Bright velvet, shaded tose and gold. A pretty pompon.

Pietro Diaz - Fine mahogany red, silver shadings. If you wish to exhibit you can't do without this variety.

Syringa-Pure lilac in color. A most beautiful variety.

Source d'Or-Golden twisted florets, tipped yellow, and shaded with brown.

Tokio - Cinnamon red, with scarlet shadings. An elegant plant. Properly disbudded there is not a prettier for specimens.

Timbal d'Argent-Pure white; anemone flowered. Very fine for cut flowers.

Unique-A twisted lapanese. Bright golden yellow in color. A veritable curiosity, as well as an interesting sort.

From above list three of a kind in dozen lots, five of a kind in roo lots at 50 Cents per I $2, \$ 4.00$ per 100 .

We will send Ioo Chrysanthemums fifty choice varieties for \$5.00. 


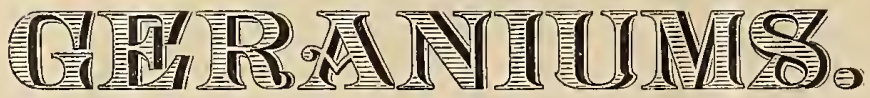

\section{NOVELTIES FOR 1889.-DOUBLE VARIETIES.}

M. PRESS-Rosy salmon color, shaded with carmine and white. Good bearing variety.

GOEFFREY ST. HILARE-Dark cerine red in color, shaded violet. Large fine trusses of flowers.

MATHIAS SANDORF-Flowers large and nicely shaped. Color, orange salmon shaded with silver and capucine.

M. JOVIS-Trusses of immense size. Color, salmon bordered with white and shaded cream.

MISS DOBBIE-Very large florets. Very rich rose in color.

ELYSEE-Bright cramoisy red. Very large florets.

A. DUPRE-Cramoisy red. Large trusses.

M. DIEULAFOY - Gigantic trusses. Tender rose color.

BARON DE LAYRES-Semi-double. Pure white variety.

F. ESCUDORO-Purplish red, shaded with orange.

PRINCE HENRY-Large round trusses. Deep rose shading, lighter at centre.

CREPUSCLE-Cramoisy purple, centre shading to light red.'

FRASCATI-Brilliant cerise scarlet, shaded purple.

DERUCHETTE-Light rose, bright. Very dwarf.

TUNISIE-Bright, clear salmon, lined lighter.

M. JANSSEN-Rosy carmine flower. Large trusses.

L. DURANT-Purple rose, blotched with cream.

LA FAVORITE-Pure white. Large trusses.

SOUVENIR-Salmon shade, tinted orange.

CHARLES JOLLY - Bright salmon rose; tinted and lined.

L. CONTABLE-Bright rose.

The above set of sixteen varieties for $\$ 2.00$.

\section{NOVELTIES IN SINGLE VARIETIES FOR 1889.}

BALMONT FRERES-Salmon flesh color, with large white center, upper petals carmine.

FULMINANT-Large finely-formed trusses of the mosc brilliant crimson, with a very distinct white eye.

LUMIERE ELECTRIQUE-Color, very rich crimson, surrounded with orange, upper petals shaded with flaming orange.

MISSOLONGHI-Large round flower: salmon apricot color, surrounded with beautiful rose.

VICTORIEN SARDOU-Violet currant color, upper trusses marked very distinctly with capucine.

AVENIR--Enormous sized trusses, dark violet, tinted with clear rose on the upper petals. PAUL DUPUIS--Rosy white, with a very large and distinct carmine eye. Extra fine. PERLE-Pure snowy white, purer in color than "Queen of the Belgians."

RENAISSANCE--Grayish rose, with white center, upper petals flamed with orange.

TROPHEE-Rosy flesh color, tinted at the center with lilac, changing to dark lilac.

LEON PERAULT--Bright scarlet ; recommended for niassing.

LORD BYRON-A most exquisite salmon, white eye.

MONTAIGNE-Bright carmine rose color. Large trusses.

INGENIEUR CLEVELAND-Brilliant red; plant dwarf. Good for massing. 
M. JADOUL-Bright cerine carmine, shaded orange.

M. MICHEL-Violet rose, marked white on upper petals.

POMPEII-Cinnamon scarlet, white eye. Excellent.

CARBONARA-Currant red. Immense spherical trusses.

M. DUPONCHEL-Lavender rose, upper petals orange salmon.

The above set of nineteen single varieties for $\$ 2.00$.

\section{New Geraninms.}

\section{DOUBLE.}

LE PROPHETE-One of the most magnificent double scarlet Geraniums ever grown. Perfect in size, shape, habit and color; not equaled in its line of color.

LE SID-Very compact, but vigorous in growth and of a perfect habit. Color, brilliant crimson red, size and truss all that could be desired.

CENTAUR - Carries the largest and most perfect truss of any of the pink doubles. A grand bedder of compact growth.

AIMEE GOUBIN--Violet crimson, scarlet shading, very large individual florets, of superb form, carries immense trusses.

APRICOTE-A fine, semi-double apricot-colored flower. Very circular, and of good outline. Medium sized trusses. A good Geranium.

C. A. KNORR-Bright lilac red, shaded lilac, with maculated red spots on upper petals. A very effective and novel colored Geranium.

JULES LARTIGUE-Flowers semi-double; upper petals shaded carmine, base of petals violet lilac. Moderate in growth, with a free blooming habit.

MARIE DE BISNARY - Very beautiful rose, chamois color; center of petals shaded rosy lilac. Quite distinct and pretty.

CLEOPATRA-Florets tirited and shaded with salmon, center salmon-orange. Very dwarf and exceedingly free flowering. A decidedly pretty Geranium.

M. DAVID-Bright rosv-carmine, marked white on the upper petals. A very pretty and unique semi-double Geranium.

The above varieties $\$$ I.oo per I 2 .

\section{SINGLE SORTS.}

ALPHONSE DAUDET-Florets of excellent shape and size, with large trusses. Stands sun well. Color a reddish salmon, with much darker center. A very superior variety.

PROTEE-Florers of good size, borne in large trusses; color, clear silvery-lilac passing to light rose. Good foliage and habit.

INGENIEUR FOREY-Florets light salmon borders of the petals pure salmon. Immense trusses, presenting a perfect ball of flowers of great size. A number one.

BLANCHE MOULAS-Very light salmon, edged and bordered white. This will prove a grand bedding variety of wonderful merit.

GEORGES PASCATD-Another most beautiful light salmon with shadings of white. Stands sun well, and is a Geranium of rare merit.

SCEPTRE ROSE-A light colored variety, with a distinct white spot on upper petals. Large, compact trusses.

BARON DU PAYNODE-Extra large florets borne on strong footstalks in immense trussses. Color, orange-vermillion, white center or eye. Stood heat and sun well.

COLUMBUS GEM-Extra large florets of perfect shape, form in large trusses, well above the foliage, of a bright varied pink, with a large clear white eye. Will prove a variety of merit.

Each ro Cents, \$I.00 per I 2. 


\section{New Geranimms of Special Merit.}

I wish to call the attention of the Trade to the following new and scarce Geraniums, they are distinct varieties of great merit.

\section{DOUBLE VARIETIES.}

LE XIV JUILLETT - Plant very dwarf and bushy, but vigorous. Monstrous trusses on long footstalks. Color, a rich salmon intermingled with white. \$1.oo per dozen.

ESPERANCE-Compact and dwarf in growth with good foliage. Color of the rose, Malmaison, center salmon with shadings of salmon. \$I.Oo per dozen.

GENERAL DECORUCY - Large, round trusses of great size. Color, bright brick red, shaded with salmon and tinted with white. \$I.oo per dozen.

GLORIE DE FRANCE-Large, round individual flowers; habit all that could be desired for pot purposes. Color, salmon white, with a dark distinct salmon red center. \$1.00 per dozen.

GERTRUDE-Color, clear bright salmon, with center and outer edges touched with white, a fine striking flower. \$I.OO per dozen.

SERGENT BLANDAN-Florets large and distinct. Color, rich orange scarlet. Immense trusses, long footstalks. \$I.oo per dozen.

SERGENT BOBILLOTT-Color, beautiful vincus rose with distinct white center. This variety produces fine individual florets, and combined with its other good qualities makes it a valuable Geranium., \$1.00 per dozen.

S. S. NUTT-Rich crimson, dark trusses, massive and profuse. \$I.OO per dozen.

MARVEL-Dark crimson maroon, extra fine variety. \$I.OO per dozen.

HARRIETT THORP-Delicate plush, shaded with pearl, pink trusses, large well shaped, habit perfect, a splendid variety. \$I.oo per dozen.

L.A VIENNI-Probably the finest double white, trusses extra large, fine form, pure white, no tint, "a good thing." \$1.oo per dozen.

GOLDEN DAWN-One of the golden scarlets and a decided advance on the yellow color. \$I.Oo per dozen.

MADAM HOSTE-Color, flesh, shaded white and salmon, an extraordinary fine variety. \$I.OO per dozen.

BELL NANCIENNE--Center of flower rich, warm crimson, outside of this is a creamy bank with an outer margin of bright deep blush. \$I.00 per dozen.

MME. MENOREAU-Pure white, rich salmon center. \$I.oo per dozen.

RE UMBERTO-Brilliant orange red, with yellow shadings, the new French yellow, and without a doubt the finest yellow Geranium. \$I.OO per dozen.

\section{SINGLE FLOWERING VARIETIES.}

CHRISTOPHER COLOMB-Enormous trusses, freely produced; bright crinnabar orange color; very distinct and fine of bushy growth. \$I.oo per dozen.

FRANCIS ARAGO--Flowers finely formed and produced in the greatest abundance on strong footstalks; a very distinct variety. Color, silvery salmon shaded peach. \$1.0O per dozen.

ARC-EN-CIEL--The trusses of this variety exceed in size, nearly all the single flowering Geraniums ; the style of growth, large individual florets, combined with a perfect habit, puts it to the front as a market variety. Color, lake red, upper petals marked with orange scarlet. A novel and distinct colored Geranium. \$1.00 per dozen.

POET NATIONAL-Round florets, nicely displayed,an cxira fine fancy variety. Color, of Baroness Rothschild rose, deepening to soft rosy peach. \$I .oO per dozen. 
LOUIS UHLBACH - Color, intense dazzling scarlet, trusses extra large, florets round and large, an excellent bedder. \$I.oo per dozen.

JULES FERRY - Splendid trusses on long rigid tootstalks, which are held well above the foliage, not a coarse grower but the ideal of a bedding Geranium for massing. Color, soft scarlet red; stands the sun finely. \$1.oci per dozen.

RENAN-Exceedingly free flowering, fine large trusses, fine pot plant. Color, bright salmon apricot, with bright shadings. \$I. oo per dozen.

VICTOR HUGO-Plant dwarf and floriferous, trusses large, flowers fine form and finish, a brilliant şalmon, a strikingly fine Geranium. \$1.00 per dozen.

SWANLEY GEM - An English variety of exceptional merit. Color, rosy salmon red, with large white eye. A fine market pot plant. \$I.OO per dozen.

SAM SLOAN-A fine bedding variety. Color, deep velvety crimson, large truss and very free flowering. \$I.00 per dozen, \$6.00 per Ioo.

\title{
$\rightarrow$ *Geranin111. $\}_{6}$
}

\section{GENERAL COLLECTION OF STANDARD SORTS SINGLE AND DOUBLE.}

Our stock of Geraniums is large, of the leading pot and bedding varieties. 50 Cents per I $2 ; \$ 3.00$ per 100 .

\author{
IVY GERANIUMS.
}

In ten choice varieties, per I 2, 50 Cents; per 100, $\$ 4.00$.

\section{SCENTED GERANIUMS.}

In five varieties, 50 Cents per I $2 ; \$ 4.00$ per IOO.

\section{GERANIUMS.}

Happy. Thought, Mt. Snow, Bronze and Md. Sallerdi, \$4.0o per Ioo.

\section{COLEUS.}

Best market varieties, 40 Cents per I $2 ; \$ 3.00$ per Ioo.

ANTHEMUS CORONARIA (New Double Yellow Daisy)-A grand plant of recent introduction; quite valuable, either as pot or bedding plant, being continuously in bloom with a perfect mass of golden yellow flowers. For market plant this has few equals. 50 Cents per dozen ; $\$ 4.00$ per IOO.

ASPARAGUS TENUISSIMUS - This will become indispensable to Florists to cut from ; its fine spraying foliage working well with cut flowers remaining green several after being cut. It can be grown like smilax bedded out or grown in pots; makes a fine decorative plant. 4 -inch strong plants $\$ I$ I. Oo per dozen.

ASPIDISTRA LURIDA-One of the best house and decorative tropical plants ; large olive green leaves sixteen to twenty inches long. Each Io Cents; per dozen 75 Cents; $\$ 5.00$ per IoO.

ALTHERNANTHEAS - AUREA NAN, best yellow and PARACHOIDES MAJOR, best red. 50 Cents per dozen ; \$3.00 per Ioo. Ready May Ist.

HELIOTROPES --Best market varieties. 50 Cents per dozen; \$4.oo per Ioo.

IPOMEA NOCTIPHYTON OR MOON FLOWER-As a rapid growing vine this has no equal for verandas, arbors, etc. This has the ideal growth and when covered with its pure white flowers, five inches in diameter, is a grand sight; will be in general demand. Each Io Cents ; 50 Cents per dozen; $\$ 4.00$ per Ioo.

IVY GERMAN OR PARLOR-40 Cents per dozen ; \$3.00 per roo.

\section{OXALIS}

LUTEA FLORA PLENO-Double yellow. 50 Cents per dozen.

FLORABUNDA ALBA AND ROSEA--5o Cents per dozen.

CEREUS GRANDIFLORIUS-Night Blooming Cereus. 75 Cents per dozen.

EUPHORBIA SPLENDENS-Stems densely covered with spines of cactus like ap. 
pearance, flowers freely produced of an orange red color ; strong plants. 5o Cents per dozen; $\$ 4.00$ per 100.

HIBISCUS-Best market varieties. $2 \frac{1}{2}$ inch pots $\$ 3.00$ per 100.

POTHUS AUREA-A beautiful new trailing plant; leaves are handsomely variegated of a large heart shape, being boldly marked with blotches of cream yellow ; of a strong free growth. In strong plants $\$ 1.00$ per dozen.

\section{NEW PLUMBAGO - CAPENSIS FLORA ALBA.}

The exact counterpart of P. Capensis except in color, which in this beautiful novelty is a cream white. This is a grand addition to this useful class of plants. Each 20 Cents, \$1.50 per dozen.

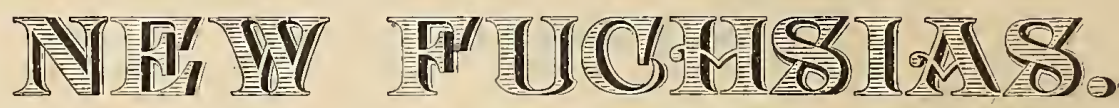

MRS. E.G. HILL-It is withthe greatest confidence that we call the attention of the trade to this superb double white Fuchsia, as it will undoubtly supercede all of the leading whites of to-day. Plant of a strong robust upright growth; symmetrical in form. The short tubeand sepals are a bright rich crimson color corolla extra large, full and double flower of the largest size. Each 20 Cents, per 12 $\$ 2.00$; per 100 $\$$ I 2.00. See Cut.

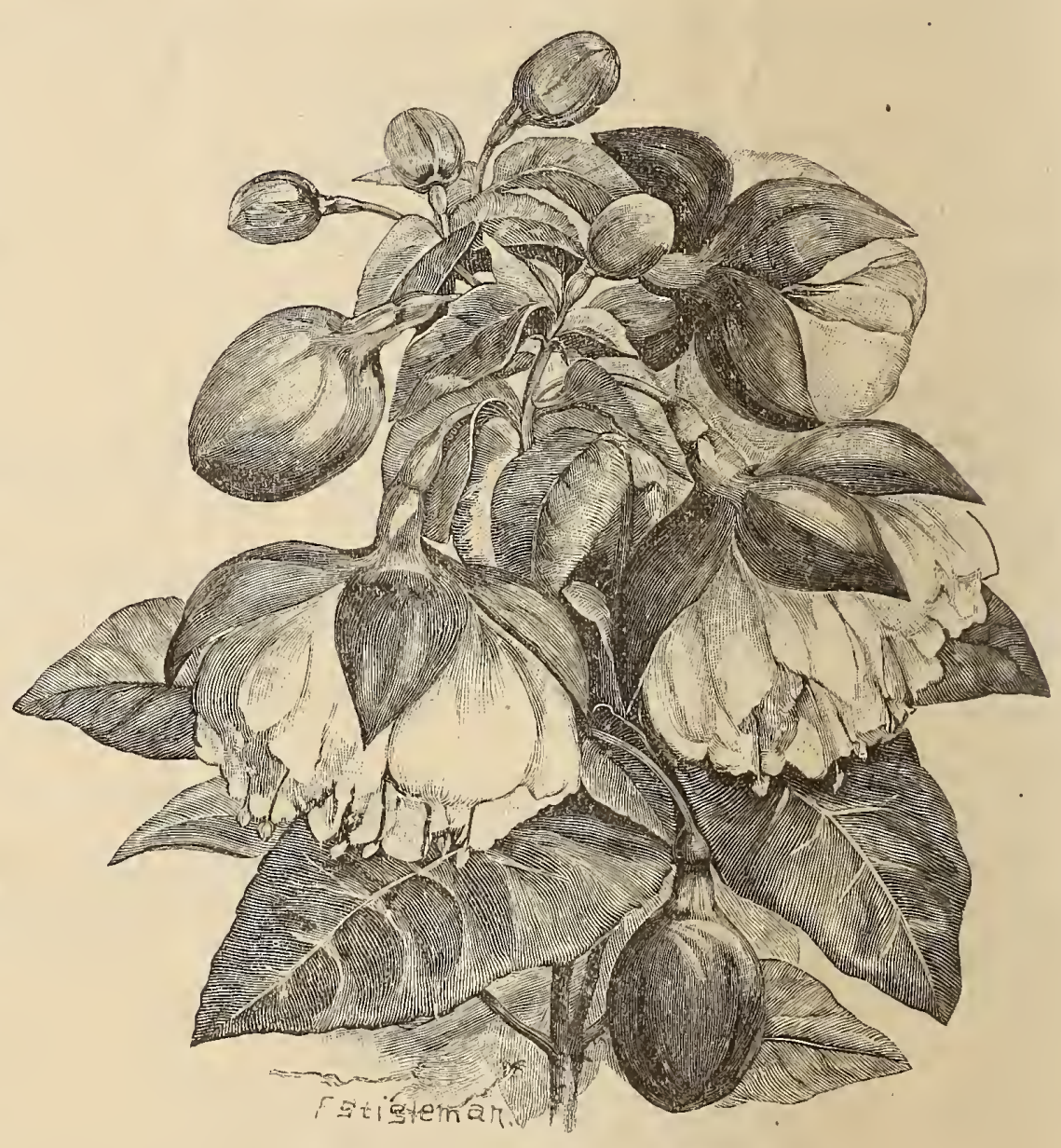

MRS. E. G. HILL. 


\section{GENERAL ROBERTS.}

A remarkably beautiful variety of drooping habit; the blooms are from four to five inches in length; borne in large clusters; single corolla, of a rich plum color; tube and sepals crimson. (See Cut back of cover.) Each I 5 Cents, per dozen \$I.5O, per 100 \$I 2.

\section{Finclisias.}

We have a fine stock in leading varieties, both single and double. Per dozen 50 Cents, per $100 \$ 3.00$.

\section{GENERAL LIST.}

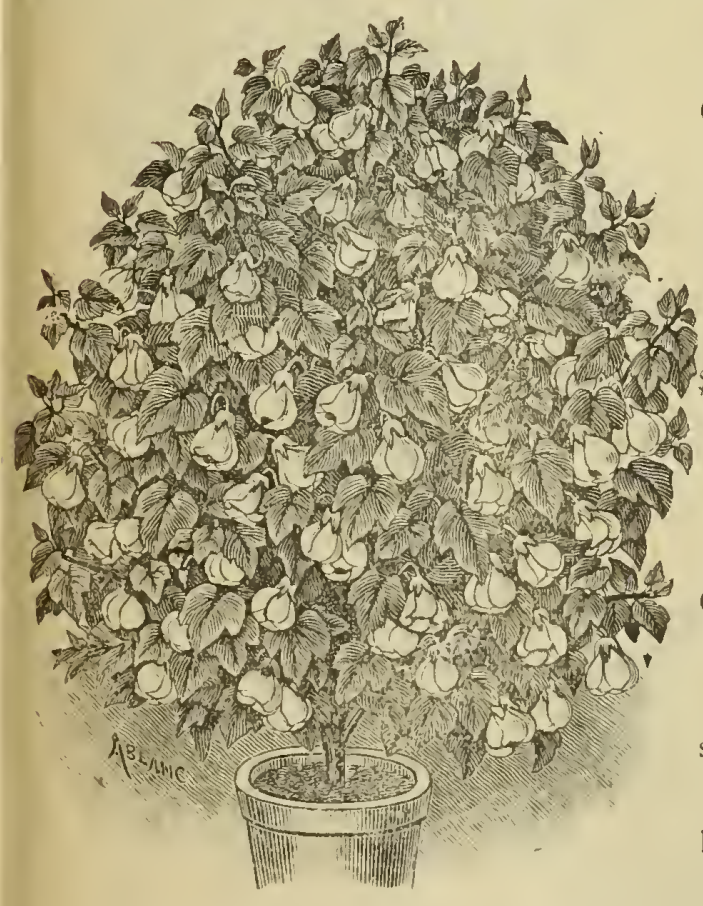

Abutilons--Per dozen 50 Cents, $100 \$ 4.00$.

Abutilon Golden Fleece--Per dozen 75 Cents, $100 \$ 6.00$.

Astilbe Japonica (strong)--Per Ioo \$6.00.

Alyssum -Double white; $\$ 4.00$ per 100.

Cuphea-Per $100 \$ 3.00$.

Callas--2-inch, 3-inch, 4-inch, 5 and 6 -inch, $\$ 4, \$ 8, \$ 15, \$ 25$ per 100 .

Coleus-General assortment; $\$ 3.00$ per Ioo.

Feverfew-Per IOo $\$ 3.00$.

Ficus Lanceolata-4-inch pots, each 35 Cents.

Farfugium Grande-\$I.50 per dozen.

Honeysuckles-Three varieties, mailing size, $\$ 4.00$ per 100 .

Hoya Carnosa (Wax Vine) -75 Cents per dozen.

Hyderangea P. Grandiflora--2 years, \$1

NEW ABUTILON GOLDEN FLEECE. per dozen.

Lemon Verbeneas -75 Cents per dozen; $\$ 5.00$ per 100.

Heliotrope -Best market varieties. 50 Cents per dozen, \$4.00 per Ioo.

Smilax--50 Cents per dozen, $\$ 4.00$ per Ioo.

Saivias- $\$ 4.00$ per 100 .

Pentstemons $\rightarrow 75$ Cents per dozen

Passion Vine--5o Cents per dozen.

Petunias-Best market varieties; 50 Cents per dozen, \$4.00 per Ioo.

Pansy "Thorps" -Famous strain. \$I.5O per IOo.

Tradescan'ia Multicolor-A strikingly variegated trailing plant, leaves longitudinally striped with purple, scarlet and white; fine for baskets. Our stock is well colored. 50 Cents per dozen; $\$ 4.00$ per Ioo.

Pæonia Fragrance-75 Cents per dozen, $\$ 5.00$ per 100.

"Twelve selected varieties for $\&$ I. 50 .

Verbeanas-Mammoths and best of old varieties, $\$ 2.50$ per 100 : 


\section{$\rightarrow *$ Cannas. $t_{6}<$}

Brilliantissima-A rich dark colored foliage, upright foliage; height six to eight feet; in pots $\$ \mathrm{I} .5 \mathrm{O}$ per dozen.

Ehemanii--Large deep green leaves; brilliant crimson flowers; height five to seven feet; in pots $\$ \mathbf{I} .50$ per dozen.

La Tour du Grand Roude--The most beauti ful of the high colored Cannas. In pots $\$ I .50$ per dozen.

Nouttonii-A superb variety; flowers richer than Ehemanii. In pots per dozen $\$ 2$.

\section{TUBEROSE EXTRA STRONG.}

Fine bulbs-- $\$ 2.00$ per 100.

Second size but flowering bulbs $\$$ I. .0 per Ioo.

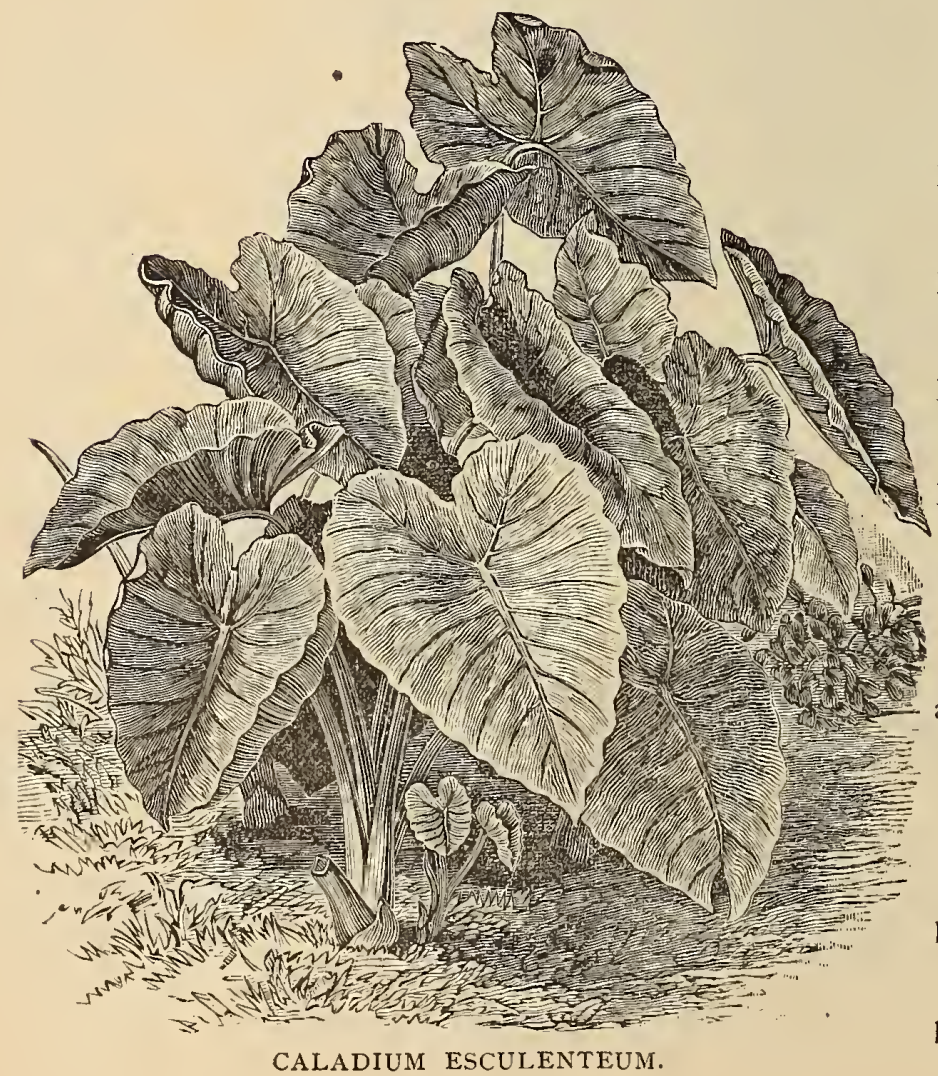

CANNA EHEMANII.

CALADILII ESCULENTEUM.

Ist size, strong bulbs, $\$ 8.00$ per IOO.

$2 \mathrm{~d}$ size,strong bulbs, $\$ 6.00$ per Ioo.

3 d size, strong bulbs, $\$ 4.00$ per Ioo.

$4^{\text {th }}$ size,strong bulbs, $\$ 2.50$ per IOo.

RICHARDIA OR SPOTTED CALLA.

Strong bulbs $\$ 8.00, \$ 6.00$ and $\$ 4.00$ per 100 .

\section{GLADIOLLS}

Red and scarlets, \$I.50 per IOO.

Strictly light colors, $\$ 2.00$ per Ioo. 



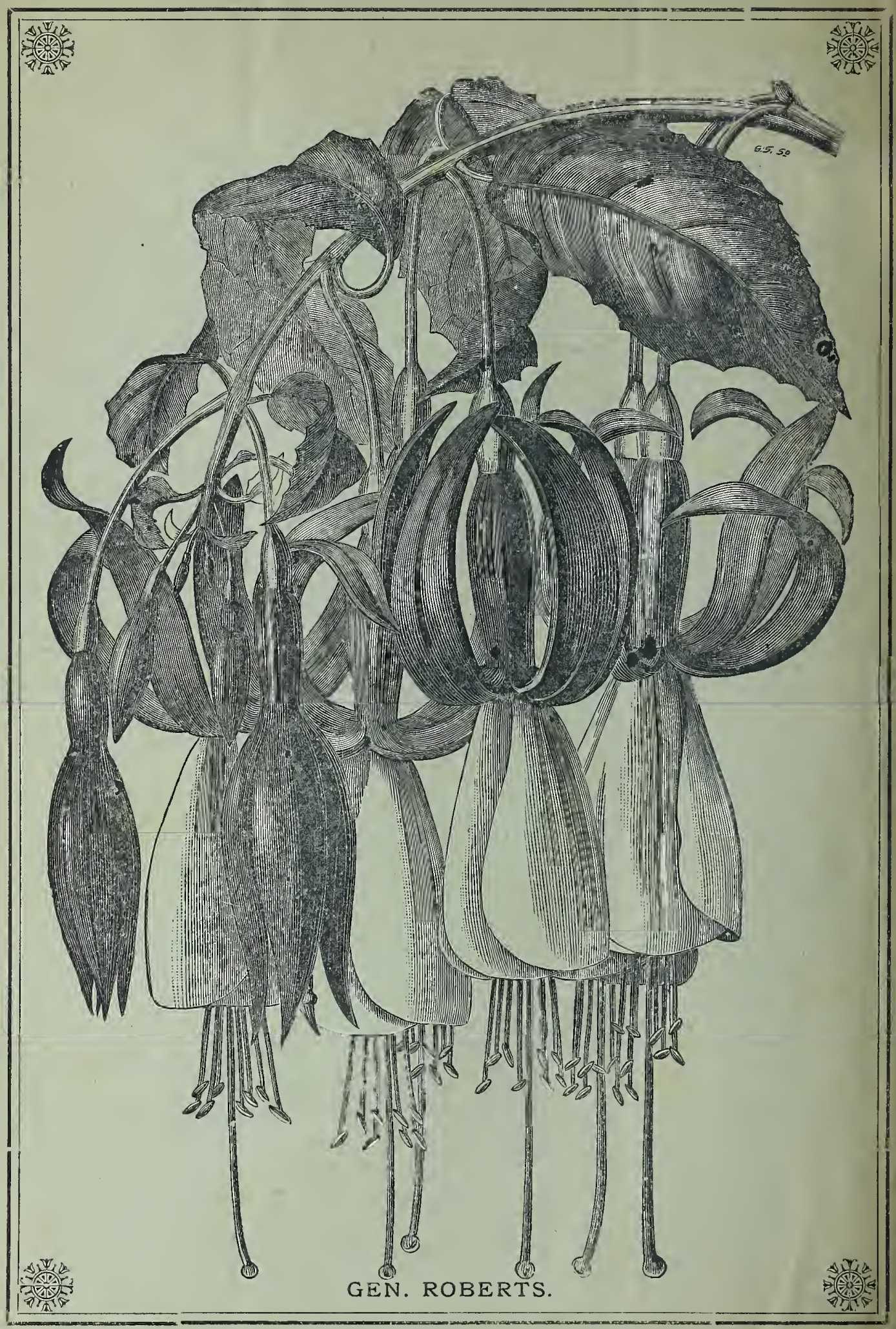

